Article

\title{
Phylogenetic Affinity of Genolopa (Digenea: Monorchiidae) with Descriptions of Two New Species
}

\author{
Apryle J. Panyi *, Stephen S. Curran and Robin M. Overstreet \\ Gulf Coast Research Laboratory, The University of Southern Mississippi, 703 E Beach Drive, Ocean \\ Springs, MS 39564, USA; stephen.curran@usm.edu (S.S.C.); robin.overstreet@usm.edu (R.M.O.) \\ * Correspondence: apryle.panyi@usm.edu
}

http://zoobank.org/urn:lsid:zoobank.org:pub:A7C45440-BF7F-4F0C-A3B1-D251A208E04C Received: 18 December 2019; Accepted: 21 January 2020; Published: 28 January 2020

\begin{abstract}
The validity of Genolopa Linton, 1910 has been controversial because the observation of presently recognized critical diagnostic morphological features (spines in the genital atrium and a bipartite, anteriorly spined terminal organ) were omitted from the original diagnosis, and these features were not universally appreciated as important diagnostic features until 2008. Modern taxonomists have been further challenged by inappropriate fixation techniques that have resulted in various interpretations of morphological features. Consequently, named species in the genus have fluctuated among other monorchiid genera depending on various interpretations by taxonomists, and a modern consensus on classifying these species is lacking. This study combines a molecular approach with modern conventional morphological techniques to investigate the validity of Genolopa as a lineage within the Monorchiidae. New morphology and molecular sequence data from the type-species of Genolopa were studied, and two new species in the genus were described, Genolopa vesca n. sp. and Genolopa minuscula n. sp. Interrelationships among the Monorchiidae were explored using Bayesian inference analysis of the partial $28 \mathrm{~S}$ rDNA fragment, incorporating three species of Genolopa for the first time. The phylogenetic analysis revealed that the genus represents a natural lineage, supporting the presence of spines in the genital atrium in conjunction with a bipartite and anteriorly spined terminal organ as key features of the generic diagnosis. This study also provides for the first time partial 28S rDNA data for Postmonorchis orthopristis, Lasiotocus trachinoti, Lasiotocus glebulentus, and an unidentified species of Lasiotocus.
\end{abstract}

Keywords: Genolopa ampullacea; Genolopa vesca n. sp.; Genolopa minuscula n. sp.; Lasiotocus spp.; Lasiotocus glebulentus; Lasiotocus trachinoti; Postmonorchis orthopristis; 28S; Atlantic Ocean

\section{Introduction}

The Monorchiidae is a family of internal flukes (Trematoda: Digenea) parasitizing primarily estuarine and marine fishes globally as adults. There are currently over 250 nominal species of monorchiids in approximately 40 genera [1]. Known monorchiid life cycles consist of three hosts: a molluscan first intermediate host, an invertebrate second intermediate host (usually another mollusc), and a molluscivorous fish definitive host $[1,2]$. However, the first or second intermediate host is known for only 14 monorchiid species [3-6].

Taxonomy of monorchiids is based on morphological features present in adult stages like with most digenean families, and classification of the family has most recently been summarized by Madhavi [1]. The status of Genolopa Linton, 1910, originally erected for Genolopa ampullacea Linton, 1910 that parasitizes grunts (Perciformes: Haemulidae) in the Dry Tortugas near southern Florida, USA, has been controversial among taxonomists for nearly a century. Early confusion and controversy regarding the genus stemmed primarily from the failure by Linton to report genital atrium spination in his descriptions. Various taxonomists interpreted Linton's species in opposing ways and advocated 
conflicting classifications of the species into other monorchiid genera [7-12]. Manter [8] noted that spines present in the genital atrium in Linton's specimens represent an important generic feature. Manter [8] also described the cirrus and terminal organ spines from the type specimens and additional specimens of G. ampullacea he collected from the Dry Tortugas.

Currently, the presence of spines in the genital atrium, along with the presence of a bipartite, anteriorly spined terminal organ are used as the primary features differentiating Genolopa from other similar monorchiid genera. For example, the diagnoses for Lasiotocus Looss, 1907, Proctotrema Odhner, 1911, and Parachrisomon Madhavi, 2008 are similar to that of Genolopa; however, these three genera all consist of species that lack spines in the genital atrium. The diagnoses for three other monorchiid genera (Proctotrematoides Yamaguti, 1938, Paraproctorema Yamaguti, 1934, and Monorchicestrahelmins Yamaguti, 1971) are also similar to that for Genolopa. Proctotrematoides is diagnosed by having spines in a distinctive muscular, "flask-shaped" diverticulum attached to the genital atrium [13]. The diagnosis for Paraproctorema includes presence of spines in the genital atrium similar to the arrangement in Genolopa spp., but the terminal organ is unipartite in Paraproctotrema spp. rather than bipartite, the terminal organ is fully spined rather than partially spined, and a conspicuous bulb-like sphincter occurs where the uterus meets the terminal organ. Similarly, the diagnosis for Monorchicestrahelmins includes spines in the genital atrium, but Monorchicestrahelmins spp. have a unipartite, spined terminal organ without a bulb-like sphincter where the uterus meets the terminal organ [1].

Investigation of the accepted classification of the Monorchiidae using modern molecular techniques is highly desirable. To date, a paucity of molecular sequence data is available for members of the Monorchiidae. Only 15 of the approximately 40 monorchiid genera are represented in publicly accessible sequence databanks, and only three representative publicly available sequences are from the genera mentioned [4,6,14-23]. Only two genera have sequences of species from western Atlantic monorchiids $[17,24]$. Currently, no species of Genolopa is represented among the publicly available molecular data.

This study utilizes novel molecular sequence data from three species of Genolopa, including the type-species (G. ampullacea), to estimate the phylogenetic position of the genus among other monorchiids. Reliability of the two generic-level features currently used to differentiate species of Genolopa from other monorchiid genera (presence of a spiny genital atrium, and bipartite, anteriorly spined terminal organ) is scrutinized here using molecular analysis. We also describe two new species of Genolopa from fishes from the Florida Keys, USA, and additionally provide molecular sequence data for Postmonorchis orthopristis Hopkins, 1941 and three species of Lasiotocus.

\section{Materials and Methods}

\subsection{Specimen Collection and Morphological Analysis}

Various hosts (listed in the taxonomic summaries sections with specific localities) were sampled using baited hook and line and cast nesting from areas Florida, USA (April 2017, March 2018, August 2018, September 2018), North Carolina, USA (August 2018), and New Jersey, USA (August 2018). Worms were collected from fish held on ice for no more than $12 \mathrm{~h}$ after capture following the methods described by Cribb and Bray [25]. One modification to the methods of Cribb and Bray [25] was post-fixing some worms in $10 \%$ formalin specifically for morphological analysis after they had originally been preserved in $70 \%-80 \%$ ethanol. Preserved worms were hydrated using distilled water, stained using VanCleave's hematoxylin or Mayer's hematoxylin, de-stained following methods of Curran et al. [26], and dehydrated in a graded ethanol series, before being cleared in clove oil or methyl salicylate. Cleared specimens were mounted on microscope slides in Canada balsam or Damar gum. Morphological data were collected using an Olympus BX53 compound microscope in conjunction with iSolutions Lite (Version 8.2) (C) software (IMT, Inc., Vancouver, BC, Canada). Measurements are provided as ranges in micrometers $(\mu \mathrm{m})$ and, where appropriate, followed by the measurement taken directly from a holotype in parentheses. Specimens were illustrated using a drawing tube and 
then digitized using Adobe ${ }^{\circledR}$ Photoshop ${ }^{\circledR}$ CS6 (Adobe Inc., San Jose, CA, USA). The type series for G. ampullacea was borrowed from the Smithsonian National Museum of Natural History (USNM), Washington DC, USA, for comparison with the present material. Herein we defined the regions of the bipartite terminal organ relative to the body axis of the worm. The "anterior region" of the terminal organ was the part that opened into the genital atrium, often spined, and the "posterior region" of the terminal organ was the blind portion that was opposite the anterior region, often not spined, vesicular, as defined by Madhavi [1] in reference to bipartite terminal organs. We did not use "proximal/distal" terminology in reference to regions of the terminal organ because those terms have been defined in contradicting ways previously when applied to the monorchiid terminal organ [1,27]. We also wanted to clarify our use of the terms dextral and sinistral. These terms were observer-independent, as if viewed from the body/specimen, not the view of the illustration. Additionally, we defined the terms median and submedian relative to the longitudinal axis or median plane that bisected a bilateral animal into two mirrored halves.

\subsection{Molecular Sequencing}

Molecular vouchers consisted of hologenophores and paragenophores [28]. Paragenophores were cleared in nuclease-free water, wet-mounted, and photographed for further potential morphological analysis before extraction [24]. Genomic DNA was extracted from molecular vouchers using a QIAgen DNAeasy blood and tissue kit (Qiagen Inc., Valencia, CA, USA) following the manufacturer's instructions modified to extend the initial tissue lysing stage to $18 \mathrm{~h}$.

The complete second internal transcribed spacer unit (ITS2) and the partial 28S rDNA regions (including domains D1-D3) were targeted and amplified from the extracted DNA by polymerase chain reaction (PCR) using a MJ mini cycler (Bio-Rad, Hercules, CA, USA). The ITS2 rDNA region was amplified using the forward primer ITSf and the reverse primer 300R [29]. Internal sequencing primers for the ITS2 rDNA region included digl2r [29] and d58r [30]. The partial 28S rDNA region was amplified using the forward primer digl2 [29] or LSU5 [31] and the reverse primer 1500R [29] targeting the $5^{\prime}$ end of the $28 \mathrm{~S}$ rDNA region. Internal sequencing primers for the partial $28 \mathrm{~S}$ rDNA region included 300F, ECD2, and 900F [29].

The PCR reactions were conducted in a total volume of $25 \mu \mathrm{L}$ that contained $10.5 \mu \mathrm{L}$ extracted DNA, $12.5 \mu \mathrm{L}$ Taq buffer (DreamTaq Master Mix 2X, Thermo Fisher Scientific, Waltham, MS, USA), and $1 \mu \mathrm{L}$ of each forward and reverse primer at $10 \mathrm{mM} / \mu \mathrm{L}$ concentration. The PCR cycling profile was as follows: 3 min denaturation at $94{ }^{\circ} \mathrm{C} ; 40$ cycles of $30 \mathrm{sec}$ denaturation at $95^{\circ} \mathrm{C}, 45 \mathrm{sec}$ annealing at $52{ }^{\circ} \mathrm{C}, 2 \mathrm{~min}$ extension at $72{ }^{\circ} \mathrm{C}$, and $3 \mathrm{~min}$ extension hold at $72{ }^{\circ} \mathrm{C}$. Samples were then held at $4{ }^{\circ} \mathrm{C}$ after completion of the reaction protocol. The PCR products then underwent gel electrophoresis; subsequent bands were cut from the gel and extracted using a QIAquick Gel Extraction Kit following the manufacturer's instructions (Qiagen Inc., Valencia, CA, USA). Sanger sequencing reactions were conducted by Eurofins Genomics LLC (Louisville, KY, USA) and GENEWIZ (South Plainfield, NJ, USA). Sequencing of the ITS2 rDNA region was successful for some of our species only. Consequently, the present phylogenetic analysis is based on sequence data from the partial $28 \mathrm{~S}$ rDNA region. The $5^{\prime}$ end of the partial 28S rDNA region was determined by annotation in the ITS2 Database using the 'Metazoa' model [32,33]. Successfully generated sequence regions were provided to GenBank and accession numbers were provided below in Table 1, taxonomic summaries, and Appendix A. Although the ITS2 sequences were not used for phylogenetic analysis in this study, they were made publicly available for use in future works.

\subsection{Phylogenetic Analysis}

Contiguous sequences were assembled using Sequencher ${ }^{\mathrm{TM}}$ version 5.0 (GeneCodes Corp., Ann Arbor, MI, USA). New sequences derived from two new species of Genolopa (found in taxonomic summaries below) and five other newly generated monorchiid sequences were combined with available partial 28S rDNA sequences of some monorchiids and related species in GenBank (listed in Table 1). 
Sequences were aligned and masked with the GUIDANCE2 web-server (http://guidance.tau.ac.il) [34,35] using the MAFFT alignment algorithm, 100 bootstrap repeats, 1000 cycles of iterative refinement, and the localpair algorithm. Alignment (column) positions with confidence scores $<0.413$ were excluded from subsequent Bayesian inference (BI) analysis [24]. The alignment was then trimmed on both ends to the shortest sequence, excluding Lasiotocus lizae because the 28S rDNA sequence was much shorter than for the other species in the alignment, and edited by eye in BioEdit (version 7.0.5) (see supplemental data for .fas alignment file). Phylogenetic analysis was conducted using BI with MrBayes 3.2.7 software [36,37]. The best nucleotide substitution model was estimated with jModeltest version 2.1.10 [38] and both the Akaike information criterion (AIC) and Bayesian information criterion (BIC) predicted the GTR $+\mathrm{I}+\Gamma$ model as the best estimator. Therefore, the BI analysis was conducted using the closest approximation to this model. The BI analysis was performed using the following model parameters: "nst $=6$ ", "rates $=$ invgamma", "ngen $=1000000$ ", "samplefreq $=500$ ", "printfreq $=500$ ", and "diagnfreq $=5000$ ". The values of the samples of the substitution model parameters were summarized using "sump". Tree and branch lengths were summarized using "sumt". The first $25 \%$ of trees were discarded using the following settings: "relburnin $=$ yes", "burninfrac $=0.25$ ". Nodal support was estimated by posterior probabilities. All other settings were left as default values. Two species in the Lepocreadiidae and one species in the Lissorchiidae were included in the alignment, with Bianium arabicum Sey, 1996 serving as the functional outgroup for the analysis [14,39]. FigTree version 1.4.3 [40] was used to visualize the phylogeny and Adobe ${ }^{\circledR}$ Photoshop ${ }^{\circledR}$ CS6 (Adobe Inc., San Jose, CA, USA) was used for subsequent editing.

Table 1. Partial 28S rDNA sequence data used in the phylogenetic analysis in this study.

\begin{tabular}{|c|c|c|c|}
\hline Species & Host Species & GenBank Accession Number & Reference \\
\hline \multicolumn{4}{|l|}{ Monorchiidae Odhner, 1911} \\
\hline Cableia pudica & Cantherines pardalis & AY222251 & [17] \\
\hline Diplomonorchis leiostomi * & Leiostomus xanthurus & AY222252 & [17] \\
\hline Genolopa ampullacea * & Haemulon flavolineatum & MN984474 & present study \\
\hline Helicometroides longicollis * & Diagramma labiosum & KJ658287 & [15] \\
\hline Hurleytrematoides chaetodoni ${ }^{*}$ & Chaetodon striatus & MH244116 & {$[24]$} \\
\hline Hurleytrematoides galzini & Gnathanodon speciosus & MK501988 & [39] \\
\hline Hurleytrematoides loi & Gnathanodon speciosus & MK501989 & [39] \\
\hline Lasiotocus arrhichostoma & Diagramma labiosum & KJ658289 & [15] \\
\hline Lasiotocus glebulentus & Mugil curema & MN984476 & present study \\
\hline Lasiotocus lizae & Liza longimanus & LN831723 & [16] \\
\hline Lasiotocus sp. & Menidia menidia & MN984477 & present study \\
\hline Lasiotocus trachinoti & Trachinotus carolinus & MN984478 & present study \\
\hline Lasiotocus typicum & Trachurus trachurus & AY222254 & [17] \\
\hline Madhavia fellaminuta & Upeneus tragula & MG920219 & [14] \\
\hline Monorchis lewisi & Acanthopagrus australis & MF503309 & {$[21]$} \\
\hline Monorchis monorchis * & Diplodus vulgaris & AF184257 & {$[19]$} \\
\hline Ovipusillus mayu * & Gnathanodon speciosus & MF503310 & [21] \\
\hline Parachrisomon delicatus & Upeneus tragula & MG920218 & [14] \\
\hline Postmonorchis orthopristis * & Haemulon flavolineatum & MN984475 & present study \\
\hline Proctotrema addisoni & Diagramma labiosum & KJ658291 & [15] \\
\hline Provitellus chaometra & Gnathanodon speciosus & MK501984 & [39] \\
\hline Provitellus infrequens & Gnathanodon speciosus & MK501985 & [39] \\
\hline Provitellus turrum * & Pseudocaranx dentex & AY222253 & [17] \\
\hline \multicolumn{4}{|l|}{ Lissorchiidae Magath, 1917} \\
\hline Lissorchis kritskyi & Minytrema melanops & EF032689 & {$[30]$} \\
\hline \multicolumn{4}{|l|}{ Lepocreadiidae Odhner, 1905} \\
\hline Bianium arabicum & Lagocephalus lunaris & MH157076 & [41] \\
\hline Lepotrema adlardi & Abudefduf bengalensis & MH730015 & [42] \\
\hline
\end{tabular}

* Indicates type-species of the genus. 


\section{Results-Morphological}

Monorchiidae Odhner, 1911

Genolopa Linton, 1910

3.1. Genolopa ampullacea Linton, 1910

\subsubsection{Taxonomic Summary}

Type host: Haemulon macrostomum (Günther, 1859), Spanish grunt, Haemulidae.

Type locality: Dry Tortugas, Florida, USA.

Other hosts reported by the cited authors but specimens not confirmed as G. ampullacea by us: Manter [8]: H. album (Cuvier, 1830), H. carbonarium (Poey, 1860), H. flavolineatum (Desmarest, 1823), H. plumierii (Lacepède, 1801), H. sciurus (Shaw, 1803), Synodus foetens (Linnaeus, 1766), Synodontidae; Manter [43]: H. aurolineatum (Cuvier, 1830), H. chrysargyreum (Günter, 1859), H. album (Cuvier, 1830), H. carbonarium (Poey, 1860), H. flavolineatum (Desmarest, 1823), H. macrostomum (Günther, 1859), H. plumierii (Lacepède, 1801), H. sciurus (Shaw, 1803), H. striatum (Linnaeus, 1758), Synodus foetens (Linnaeus, 1766); Sparks [44]: H. sciurus (Shaw, 1803); Sogandares-Bengal [45]: H. album (Cuvier, 1830), H. parra (Desmarest, 1823), H. plumierii (Lacepède, 1801), H. sciurus (Shaw, 1803); Nahhas and Cable [46]: H. album (Cuvier, 1830), H. bonariense (Cuvier, 1830), H. flavolineatum (Desmarest, 1823), H. melanurum (Linnaeus, 1758), H. sciurus (Shaw, 1803), H. striatum (Linnaeus, 1758); Rees [47]: H. flavolineatum (Desmarest, 1823); Nagaty and Abdel-Aal [48]: Cheilinus lunulatus (Forsskål, 1775), Labridae; Fischthal [49]: H. flavolineatum (Desmarest, 1823); Kohn et al. [50]: H. sciurus (Shaw, 1803); Centeno and Bashirullah [51]: H. aurolineatum (Cuvier, 1830), H. bonariense (Cuvier, 1830), H. chrysargyreum (Günter, 1859), H. melanurum (Linnaeus, 1758), H. parra (Desmarest, 1823), H. steindchneri (Jordan and Gilbert, 1882); Bashirullah and Díaz [52]: H. flavolineatum (Desmarest, 1823).

Other reported localities: Bahamas [44]; Panama and Bimini, British West Indies [45]; Curaçao and Jamaica [46]; Bermuda [47]; Red Sea [48]; Belize [49]; Rio de Janeiro State, Brazil [50]; Venezuela [51,52]; Puerto Rico [53].

Host (present study): Haemulon flavolineatum (Desmarest, 1823), french grunt, Haemulidae.

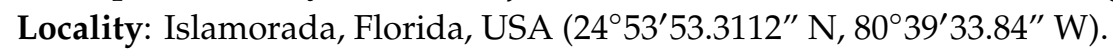

Sites: intestine, pyloric ceca.

Specimens examined: USNM 1321276 (5 syntypes).

Specimens deposited: 3 vouchers: USNM 1611654, 1611655, 16116562 hologenophores: USNM $1611657,1611658$.

Sequences deposited: Partial 28S rDNA, two identical replicates (one submitted to GenBank: accession number MN984474).

3.1.2. Supplemental Data (Figure 1) (Based on 5 Gravid, Adult Specimens from H. flavolineatum, Mounted without Pressure)

Body elongate, tapering slightly at both ends, widest near mid-body, 829 to 1265 long, 202 to 253 wide. Tegument spinose; spines larger and denser anteriorly, 4 to 6 long, 1 to 3 wide at base, smaller and less dense posteriorly, 3 to 4 long, 2 to 3 wide at base. Eyespot pigment absent. Oral sucker simple, subglobular, subterminal, 70 to 82 long or $5 \%$ to $9 \%$ of body length, 66 to 82 wide. Ventral sucker circular, weakly muscularized, near anterior third of body, 50 to 57 long or $4 \%$ to $6 \%$ of body length, 50 to 57 wide. Oral sucker to ventral sucker width ratio 1:0.66 to 1:0.77. Forebody 318 to 407 long or $29 \%$ to $36 \%$ of body length. Hindbody 519 to 833 long or $57 \%$ to $65 \%$ of body length. Pharynx slightly elongate to spherical, 36 to 40 long or 3\% to $4 \%$ of body length, 29 to 37 wide; prepharynx about as long as pharynx. Esophagus 52 to 64 long or $5 \%$ to $6 \%$ of body length with cecal bifurcation closer to pharynx than ventral sucker. Ceca extending well into hindbody, terminating 114 to 204 from posterior end or $9 \%$ to $18 \%$ of body length. 


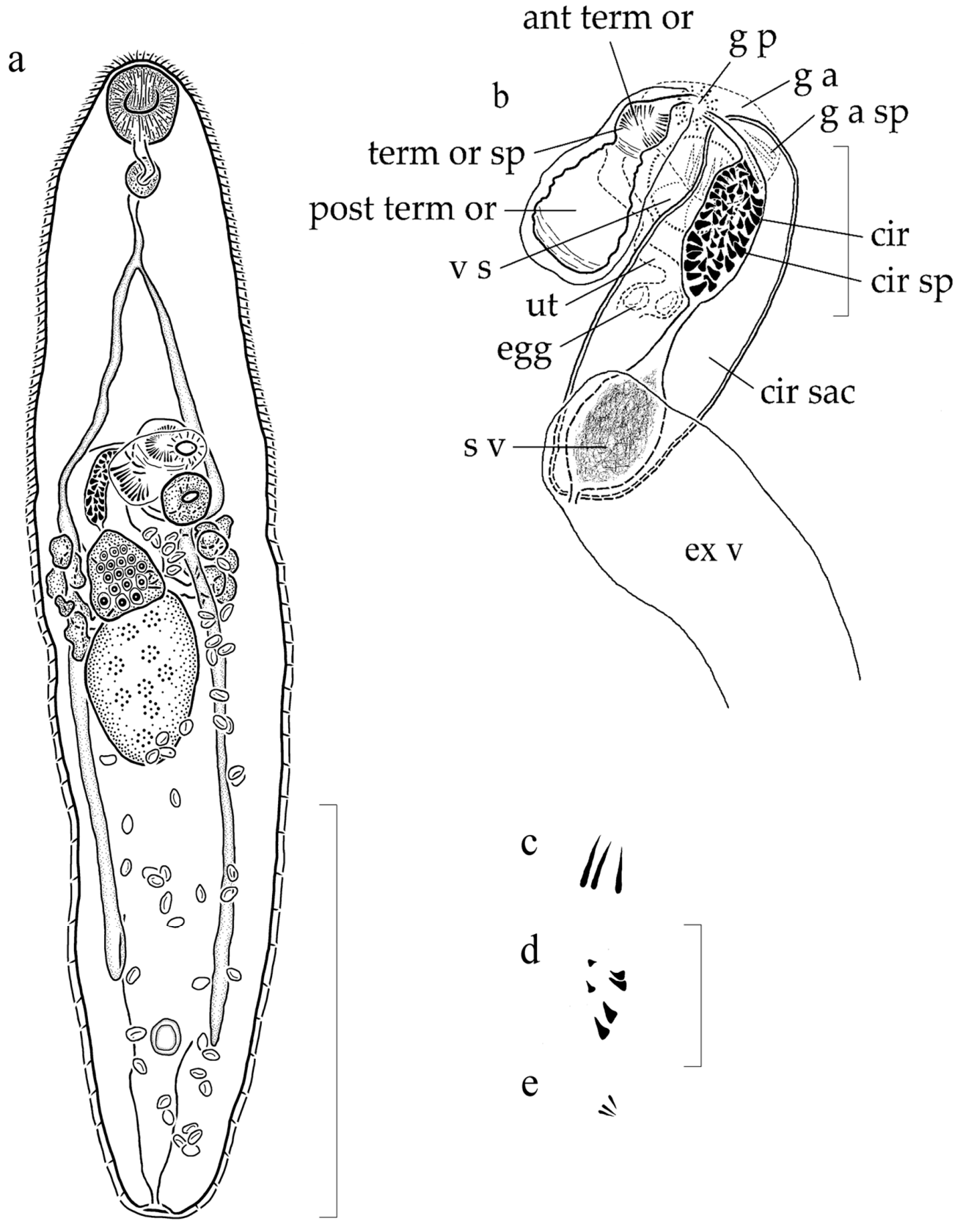

Figure 1. Genolopa ampullacea Linton, 1910, from Haemulon flavolinateaum collected for this study. (a) Ventral view, whole mount, scale bar $400 \mu \mathrm{m}$; (b) dorsal view, terminal genitalia showing anterior region of the terminal organ (ant term or), posterior region of the terminal organ (post term or), terminal organ spines (term or sp), ventral sucker (v s), uterus (ut), eggs (egg), seminal vesicle (s v), excretory vesicle (ex v), cirrus sac (cir sac), cirrus (cir), cirrus spines (cir sp), genital atrium (g a), genital atrium spines (g a sp), and genital pore (g p), scale bar $100 \mu \mathrm{m}$; (c) genital atrium spines, scale bar $50 \mu \mathrm{m}$; (d) cirrus spines, note different sized spines, scale bar $50 \mu \mathrm{m}$; (e) anterior terminal organ spines, scale bar $50 \mu \mathrm{m}$.

Testis single, subellipsoidal to slightly elongate, median to submedian, dextral, 154 to 170 long or $13 \%$ to $19 \%$ of body length, 109 to 126 wide. Post-testicular space 324 to 495 long or $35 \%$ to $39 \%$ of body length. Cirrus sac elongate, curving dextrally, dorsal to ventral sucker and ovary, opening anteriorly into genital atrium, terminating at ovarian level or mid-level of testis, 178 to 240 long or $15 \%$ to $21 \%$ of body length, 53 to 79 wide (contents consisting of internal seminal vesicle, pars prostatica, prostatic cells, and cirrus); cirrus elongate, 73 to 80 long or $7 \%$ to $9 \%$ of body length, 19 to 34 wide 
when not everted, spined; spines not uniform in size, with smaller spines anteriorly and interiorly, 5 to 8 long, 2 to 3 wide at base; larger spines posteriorly and exteriorly, 8 to 12 long, 3 to 7 wide at base; seminal vesicle unipartite, elongate, in posterior region of cirrus sac, 44 to 82 long or $4 \%$ to $10 \%$ of body length, 34 to 51 wide. Genital atrium spined; spines more numerous than depicted in Figure 1a,b; spines forming a half ring-like structure located near where cirrus entering atrium, 30 to 38 long, 1 to 3 wide at base when cirrus not everting into genital atrium. Genital pore median, opening 10 to 21 or $1 \%$ to $2 \%$ of body length anterior to ventral sucker.

Ovary subglobular to triangular, never distinctly lobed, submedian, dextral, ventral to and slightly overlapping anterior margin of testis, 67 to 85 long or $5 \%$ to $10 \%$ of body length, 61 to 81 wide. Terminal organ slightly flask-shaped when not curving ventrally into cross sectional view or constricted, distinct, bipartite, sinistral to cirrus sac, 122 to 136 long or $10 \%$ to $15 \%$ of body length, 49 to 52 wide; posterior region unspined, muscular, blind; anterior portion separated by muscular sphincter at mid-level, opening into genital atrium, spined; spines evenly distributed, 8 to 14 long, 1 to 3 wide at base. Mehlis' gland slightly antero-sinistral to ovary (observed in only one specimen). Seminal receptacle not observed. Laurer's canal descending sinistrally from region of female complex to testis level, coiling, ascending in straight line to ovarian level, opening dorsally between ovary and cirrus sac (observed in only one specimen). Vitellarium comprising 2 lateral groups of 7 to 9 follicles at ovarian level; follicles 27 to 37 long, 29 to 39 wide, meeting as common lateral duct, expanding as central, dorsal vitelline reservoir, connecting to female complex (usually obscured). Uterus voluminous, mostly intercecal, extending 28 to 55 or $3 \%$ to $6 \%$ of body length from posterior end to genital atrium, descending in coils from region of ootype at ovarian level, dorso-sinistral to testis, rarely overlapping testis, reaching posterior extent, ascending in coils ventrally, sinistral to testis, joining terminal organ at mid-level; post-testicular uterus occupying 271 to 454 or $83 \%$ to $92 \%$ of post-testicular space, $30 \%$ to $36 \%$ of body length. Eggs operculate, non-filamented, tanned, 15 to 20 long, 8 to 11 wide when distal.

Excretory vesicle I-shaped, extending to posterior end of cirrus sac, often obscured by voluminous egg-filled uterus; single concretion in one specimen; excretory pore terminal.

\subsubsection{Remarks}

Measurements derived from new and previous observations from the syntypes for G. ampullacea, from specimens collected from the southern Atlantic Ocean, and from new supplemental data are provided in Table 2 for comparison. Specimens of G. ampullacea collected and studied for taxonomic purposes prior to the present study were fixed using various methods, very commonly using an unheated acid applied to severely compressed worms; whereas the specimens used for the present supplemental data were preserved using the preferred modern method: specimens were heat-killed with near boiling water, preserved in ethyl alcohol (then post-fixed in formalin) or formalin, and mounted without added pressure. Major differences are apparent between specimens fixed under pressure and those heat-killed without pressure [54]. In flattened specimens, body width is nearly 2.5 to 3 times wider, both suckers are compressed to nearly twice their normal size, and the cirrus sac, cirrus, and terminal organs are all nearly twice as large (see Table 2). Comparison among these and other measurements demonstrates the importance of using fixation techniques that avoid artificial compression when conducting taxonomic comparisons. Furthermore, alcohol-formalin-acetic acid (AFA) and other acid fixation methods create slightly acidic conditions in the mounting medium that has been demonstrated to lead over time to the degradation of hard structures such as body spines and spines associated with terminal genitalia [55]. Indeed, tegumental spines appear degraded or are altogether lacking from areas in the syntypes of G. ampullacea, and the spines associated with the terminal genitalia are severely degraded. The present supplemental data derived from G. ampullacea from $H$. flavolineatum are provided for comparison with future works. Despite the obvious effects of fixation under pressure and with an acid, certain features present in syntypes and discernable from the available descriptions of G. ampullacea strongly suggest that the recently collected material from H. flavolineatum represents G. ampullacea. Specifically, the percentage of post-testicular space relative to 
body length, the percentage of post-testicular space occupied by the uterus relative to body length, and the percentage of post-testicular space occupied by the uterus relative to the post-testicular space all agree.

Table 2. Comparison of measurements of Genolopa ampullacea. Measurements in micrometers $(\mu \mathrm{m})$, dimensions shown as length by width.

\begin{tabular}{|c|c|c|c|c|c|c|}
\hline Reference & Linton [56] & Manter [8] & Manter [8] & $\begin{array}{c}\text { Kohn et al. } \\
\text { [50] }\end{array}$ & $\begin{array}{l}\text { Present } \\
\text { Study }\end{array}$ & Present Study \\
\hline $\begin{array}{l}\text { Material examined } \\
\text { Under pressure? }\end{array}$ & $\begin{array}{l}\text { syntypes } \\
\text { yes }\end{array}$ & $\begin{array}{l}\text { syntypes } \\
\text { yes }\end{array}$ & $\begin{array}{c}\text { new material } \\
\text { no }\end{array}$ & $\begin{array}{c}\text { new material } \\
\text { yes }\end{array}$ & $\begin{array}{l}\text { syntypes } \\
\text { yes }\end{array}$ & $\begin{array}{c}\text { new material } \\
\text { no }\end{array}$ \\
\hline Fixed with an acid? & yes & yes & $\begin{array}{l}\text { unknown } \\
\text { H. album, } H \text {. }\end{array}$ & yes & yes & no \\
\hline Host & $\begin{array}{c}H . \\
\text { macrostomum }\end{array}$ & $\begin{array}{c}H . \\
\text { macrostomum }\end{array}$ & $\begin{array}{c}\text { carbonarium, } H . \\
\text { flavolineatum, } H . \\
\text { plumierii, } H . \\
\text { sciurus, } S . \text { foetens }\end{array}$ & H. sciurus & $\begin{array}{c}H . \\
\text { macrostomum }\end{array}$ & H. flavolineatum \\
\hline Locality & $\begin{array}{c}\text { Dry } \\
\text { Tortugas, FL }\end{array}$ & $\begin{array}{c}\text { Dry } \\
\text { Tortugas, FL }\end{array}$ & Tortugas, FL & $\begin{array}{l}\text { Rio de } \\
\text { Janeiro, } \\
\text { Brazil }\end{array}$ & $\begin{array}{c}\text { Dry } \\
\text { Tortugas, FL }\end{array}$ & Florida Keys \\
\hline Genital atrium spines & - & 34 to 36 & 34 to 36 & & 30 to 36 & 30 to 38 \\
\hline Cirrus spines & - & 12 & 12 & $\begin{array}{l}5 \text { to } 10 \\
\times \\
7 \text { to } 12\end{array}$ & $\begin{array}{l}10 \text { to } 12 \\
\times \\
4\end{array}$ & $\begin{array}{c}5 \text { to } 8,8 \text { to } 12 \\
x \\
2 \text { to } 3,3 \text { to } 7 \\
8 \text { to } 14\end{array}$ \\
\hline Terminal organ spines & - & 17 & 17 & - & - & $\begin{array}{c}X \\
1 \text { to } 3\end{array}$ \\
\hline Body length & 1150 to 1420 & - & 425 to 1275 & 740 to 1580 & 1227 & 829 to 1265 \\
\hline Body width & 630 & - & 187 to 365 & $\begin{array}{l}310 \text { to } 590 \\
120 \text { to } 210\end{array}$ & 602 & $\begin{array}{c}202 \text { to } 253 \\
70 \text { to } 82\end{array}$ \\
\hline Oral sucker & $140 *$ & - & 50 to 96 & $\begin{array}{c}X \\
150 \text { to } 170 \\
49 \text { to } 82\end{array}$ & $131 \times 174$ & $\begin{array}{c}x \\
66 \text { to } 82 \\
50 \text { to } 57\end{array}$ \\
\hline Ventral sucker & 120 * & - & 34 to 62 & $\begin{array}{c}X \\
56 \text { to } 94\end{array}$ & $102 \times 58$ & $\begin{array}{c}X \\
50 \text { to } 57\end{array}$ \\
\hline Sucker ratio & & - & $3: 2$ & $\begin{array}{l}1: 0.37 \text { to } \\
1: 0.45\end{array}$ & $1: 0.33$ & $1: 0.66$ to $1: 0.77$ \\
\hline Pharynx & 40 * & - & $\begin{array}{l}17 \text { to } 40 \\
\times \\
17 \text { to } 42\end{array}$ & $\begin{array}{l}37 \text { to } 56 \\
x \\
34 \text { to } 70\end{array}$ & $63 \times 42$ & $\begin{array}{c}36 \text { to } 40 \\
X \\
29 \text { to } 37 \\
178 \text { to } 240\end{array}$ \\
\hline Cirrus sac & - & - & $225 \times 99$ & - & $351 \times 135$ & $\begin{array}{c}X \\
53 \text { to } 79 \\
73 \text { to } 80\end{array}$ \\
\hline Cirrus & - & - & - & - & $168 \times 45$ & $\begin{array}{c}X \\
19 \text { to } 34 \\
122 \text { to } 136\end{array}$ \\
\hline Terminal organ & - & - & $150 \times 85$ & - & $242 \times 106$ & $\begin{array}{c}X \\
49 \text { to } 52\end{array}$ \\
\hline Testis & - & - & - & $\begin{array}{l}150 \text { to } 300 \\
X \\
100 \text { to } 180\end{array}$ & $186 \times 155$ & $\begin{array}{l}154 \text { to } 170 \\
X \\
109 \text { to } 126\end{array}$ \\
\hline $\begin{array}{l}\text { Percentage of } \\
\text { post-testicular space } \\
\text { to body length }\end{array}$ & - & - & $33 \%$ & - & $37 \%$ & 35 to $39 \%$ \\
\hline Ovary & - & - & - & - & $113 \times 118$ & $\begin{array}{c}67 \text { to } 85 \\
x \\
61 \text { to } 81\end{array}$ \\
\hline Eggs & $17 \times 10$ & - & $\begin{array}{c}18 \text { to } 22 \\
\times \\
9 \text { to } 11\end{array}$ & $\begin{array}{l}21 \text { to } 28 \\
\times \\
9 \text { to } 12\end{array}$ & $\begin{array}{l}14 \text { to } 16 \\
\times \\
7 \text { to } 10\end{array}$ & $\begin{array}{c}15 \text { to } 20 \\
\mathrm{X} \\
8 \text { to } 11\end{array}$ \\
\hline Excretory vesicle & - & - & $\begin{array}{l}\text { I - to ventral } \\
\text { sucker }\end{array}$ & - & - & $\begin{array}{l}\mathrm{I} \text { - to posterior } \\
\text { of cirrus sac }\end{array}$ \\
\hline
\end{tabular}

* Transverse diameter.

Despite problems associated with differences in fixation techniques, G. ampullacea can be differentiated from the 12 other nominal species in the genus. Herein, G. ampullacea is compared with these other nominal species. 
Genolopa ampullacea is similar to Genolopa plectorhynchi (Yamaguti, 1934) Hopkins, 1941 but is most easily distinguished from the latter by having a subglobular, rounded oral sucker instead of a funnel-shaped oral sucker, a subglobular to triangular ovary rather than a distinctly trilobed ovary, smaller eggs ( 15 to 20 long, 8 to 11 wide compared with 26 to 29 long, 15 to 18 wide), and the cirrus spines are not bristle-like. Additionally, the description of G. plectorhynchi does not mention a spiny genital atrium; however, the illustration of the terminal genitalia of G. plectorhynchi appears to have spines surrounding the genital atrium. These spines do, however, look more similar in shape and size to those associated with the cirrus, so it is possible that the illustration shows a partially extruded spiny cirrus. We did not obtain type material of G. plectorhynchi, so we cannot confirm if true genital atrium spines exist. Genolopa plectorhynchi does have spines in the anterior region of the terminal organ.

Genolopa ampullacea may be differentiated from Genolopa brevicaecum (Manter, 1942) Manter and Pritchard, 1961 by the latter not having spines in the anterior region of the terminal organ. Additionally, the genital atrium spines shown in the illustrations of G. brevicaecum appear to be similar in shape and size to those associated with the cirrus compared with our material where there is a distinct difference in the size and shape of the genital atrium spines (30 to 38 long, 1 to 3 wide at base) compared with the cirrus spines ( 8 to 12 long, 3 to 7 wide at base). Possibly the genital atrium spines of G. brevicaecum are from a partially extruded spiny cirrus, but no measurement was given. We consider G. brevicaecum as incertae sedis because it violates the generic diagnosis by lacking spines in the anterior region of the terminal organ.

Genolopa ampullacea may be differentiated from Genolopa anisotremi (Nahhas and Cable, 1964) Yamaguti, 1971 and Genolopa pritchardae (Nahhas and Cable, 1964) Yamaguti, 1971 by neither G. anisotremi nor G. pritchardae having a spined genital atrium. Therefore, we consider G. anisotremi and G. pritchardae to be incertae sedis.

Genolopa ampullacea may be differentiated from Genolopa microsoma Lebedev, 1968 by the latter having a unipartite, unspined terminal organ and an unspined genital atrium both of which violate the generic diagnosis of Genolopa. As a result, we consider G. microsoma to be incertae sedis.

Genolopa ampullacea may be differentiated from Genolopa cheilini Nagaty and Abdel-Aal, 1972 by the latter having an unspined cirrus and an unspined genital atrium. The presence of spines on the cirrus is a family level trait. Therefore, we do not believe G. cheilini belongs in the Monorchiidae and consider it incertae sedis.

Genolopa lunulata Nagaty and Abdel-Aal, 1972 is also likely not a monorchiid. The description of G. lunulata states the tegument is smooth, i.e., unspined, and there is no description or illustration of a terminal organ; both are key features of the familial diagnosis, so we consider G. lunulata to be incertae sedis.

Genolopa ampullacea may be differentiated from Genolopa mintungensis Wang, 1975 by the latter not having spines in the genital atrium and what appear to be spines in the posterior region of the terminal organ in the illustration. We were unable to obtain the original species description for G. mintungensis, so we are relying on supplemental data from a later publication for this comparison [57]. We consider G. mintungensis to be incertae sedis because the two aforementioned features violate the generic diagnosis.

Genolopa ampullacea may be differentiated from Genolopa bychowskii Zhukov, 1977 by the latter having an unspined tegument, an unspined genital atrium and unspined terminal genitalia. Tegumental spines and a spined cirrus are key to the familial diagnosis, so we do not believe G. bychowskii is a monorchiid and consider it incertae sedis.

Genolopa ampullacea may be differentiated from Genolopa loborchis Wang, 1977 by the latter having a larger body size, a distinctly lobed ovary, an irregular, unsmooth testis, and fewer vitelline follicles per vitelline group. Additionally, it is unclear if the terminal genitalia and genital atrium are spined in G. loborchis, so we consider it to be incertae sedis, possibly at the family level if the cirrus is truly unspined.

Genolopa ampullacea may be differentiated from Genolopa mugilis Knoff and Amato, 1992 by the smaller oral to ventral sucker width ratio (1:0.53 to 1:0.58) and smaller genital atrium spine size (7 to 13 long) in G. mugilis compared with the larger sucker width ratio (1:0.66 to 1:0.77) and larger genital 
atrium spines (30 to 38 long, 1 to 3 wide at base) in G. ampullacea. The genital atrium spines of G. mugilis are more dispersed throughout the genital atrium and appear similar to the cirrus spines in size and shape compared with the genital atrium spines of G. ampullacea that form a ring-like structure of long bristles near where the cirrus enters the genital atrium.

Genolopa ampullacea may be differentiated from Genolopa magnacirrus Thatcher, 1996 by the latter having a Y-shaped excretory vesicle, apparent spines in the posterior portion of the terminal organ, and no description or illustration of a spiny genital atrium. Therefore, we consider G. magnacirrus to be incertae sedis.

We conclude, based on the review of morphological features in presently named species in Genolopa, that only three of the nominal species should be considered as valid, G. ampullacea, G. plectorhynchi and G. mugilis. This opinion is based on the fact that these are the only species that possess spines in the genital atrium and spines in the anterior region of the bipartite terminal organ. Genolopa cheilini, G. lunulata, G. bychowskii and possibly G. loborchis are considered to be insertae sedis at the family level because they do not follow the morphological diagnosis for members of the Monorchiidae. Genolopa brevicaecum, G. anisotremi, G. pritchardae, G. microsoma, G. mintungensis, and G. magnacirrus violate the generic diagnosis of Genolopa as described above and are considered incertae sedis.

\subsection{Genolopa vesca n. sp.}

\subsubsection{Taxonomic Summary}

Type host: Haemulon sciurus (Shaw, 1803), blue striped grunt, Haemulidae. Type locality: Long Key, Florida, USA ( $24^{\circ} 47^{\prime} 26.93^{\prime \prime}$ N, $80^{\circ} 53^{\prime} 2.96^{\prime \prime}$ W).

Sites: intestine, pyloric ceca.

Specimens deposited: Holotype: USNM 1611648; 4 paratypes: USNM 1611649, 1611650, 1611651, 16116521 hologenophore: USNM 1611653.

Sequences deposited: Partial 28S rDNA, 1 sequence (one submitted to GenBank: accession number MN984471); ITS2 rDNA, 1 sequence (one submitted to GenBank: accession number MN984471).

Etymology: The specific epithet is a Latin feminine adjective meaning very small in reference to the smaller tegumental spines in this species relative to the type-species.

http://zoobank.org/urn:lsid:34D4B1D8-D4BE-485B-9102-30436080EDE5

3.2.2. Description (Figure 2) (Based on 6 Gravid, Adult Specimens and 1 Non-Gravid Specimen, All Mounted without Pressure)

Body elongate, slightly tapering at both ends, narrower anteriorly, widest near mid-body, 871 to 1223 (1223) long, 188 to 276 (211) wide. Tegument spinose; spines largest and densest anteriorly, 2 to 4 long, 1 to 3 wide at base, smaller, rounded, and less dense posteriorly, 1 to 3 long, 2 to 3 wide at base. Eyespot pigment absent. Oral sucker simple, spherical to subspherical, subterminal, 49 to 74 (74) long or $6 \%$ to $8 \%(6)$ of body length, 51 to 88 (83) wide. Ventral sucker circular, weakly muscularized, between anterior half and anterior third of body, 46 to 60 (60) long or 5\% (5) of body length, 41 to 56 (56) wide. Oral sucker to ventral sucker width ratio 1:0.60 to 1:0.85 (1:0.67). Forebody 305 to 504 (504) long or $31 \%$ to $41 \%$ (41) of body length; hindbody 477 to 652 (652) long or $53 \%$ to $60 \%$ (53) of body length. Pharynx spherical to slightly elongate, 34 to 43 (43) long or 3\% to $4 \%$ (4) of body length, 33 to 40 (40) wide. Prepharynx about half length of pharynx to about as long as pharynx, 21 to 40 (40) long or $2 \%$ to $3 \%$ (3) of body length. Esophagus length variable, 35 to 101 (98) long or 3\% to 9\% (8) of body length. Cecal bifurcation closer to level of pharynx than level of ventral sucker, 147 to 266 (266) anterior to ventral sucker or $15 \%$ to $22 \%$ (22) of body length. Ceca extending well into hindbody, terminating 81 to 157 (116) from posterior end or $8 \%$ to $16 \%$ (10) of body length. 
b

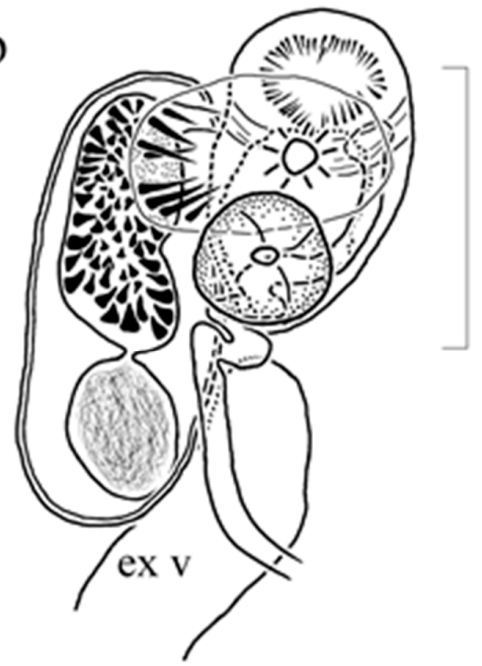

a
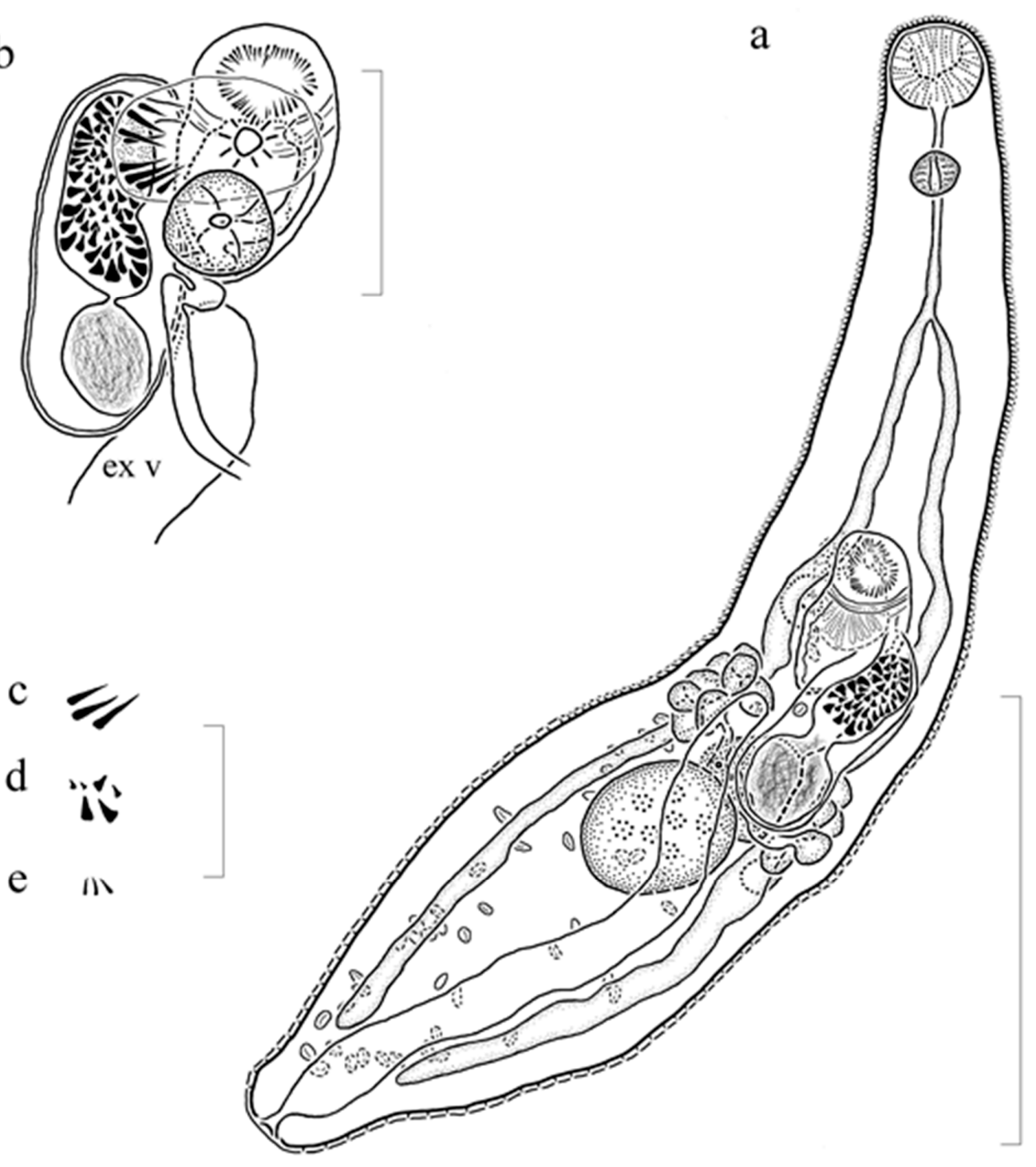

Figure 2. Genolopa vesca n. sp. from Haemulon sciurus. (a) Dorsal view, holotype, scale bar $400 \mu \mathrm{m}$; (b) ventral view, terminal genitalia and anterior extent of the excretory vesicle (ex v), note anterior portion of the terminal organ is a cross sectional view, scale bar $100 \mu \mathrm{m}$; (c) genital atrium spines, scale bar $50 \mu \mathrm{m}$; (d) cirrus spines, note the different sized spines, scale bar $50 \mu \mathrm{m}$; (e) anterior terminal organ spines, scale bar $50 \mu \mathrm{m}$.

Testis singular, subglobular to slightly elongate, median to submedian, dextral, 106 to 150 (106) long or $9 \%$ to $17 \%$ (9) of body length, 105 to 129 (105) wide. Post-testicular space 194 to 375 (375) long or $22 \%$ to $32 \%$ (31\%) of body length. Cirrus sac elongate, curving dextrally, dorsal to ventral sucker and ovary, terminating at ovarian level, 148 to 291 (193) long or 16\% to $25 \%$ (16) of body length, 59 to 76 (70) wide (contents comprising internal seminal vesicle, pars prostatica, prostatic cells, and cirrus); cirrus elongate, 86 to 102 (98) long or $8 \%$ to $10 \%$ (8) of body length, 27 to 45 (45) wide when not everted, spined; spines not evenly distributed, with larger spines posteriorly and exteriorly, 6 to 9 long, 5 to 7 wide at base; smaller spines anteriorly and interiorly, 5 to 7 long, 2 to 4 wide at base; seminal vesicle internal, unipartite, elongate to spherical, in posterior region of cirrus sac, 53 to 95 (75) long or $6 \%$ to $9 \%$ (6) of body length, 51 to 75 (75) wide. Genital atrium spined; spines forming a half ring-like structure located near where cirrus entering atrium, 35 to 43 long, 2 to 4 wide at base when cirrus not everting into genital atrium, more numerous in specimens than portrayed in Figure $2 \mathrm{a}, \mathrm{b}$. Genital pore median, 8 to 19 anterior to ventral sucker. 
Ovary subglobular to triangular, never distinctly lobed, submedian, dextral, pre-testicular or overlapping anterior margin of testis, 72 to 89 (89) long or 7\% to 9\% (7) of body length, 83 to 95 (91) wide. Terminal organ subarcuate, distinct, muscular, bipartite, sinistral to cirrus sac, 120 to 146 (144) long or $11 \%$ to $15 \%$ (12) of body length, 46 to 79 (79) wide; posterior region muscular, unspined, blind; anterior portion separated by a muscular sphincter, opening into genital atrium, spined; spines uniform, 8 to 11 long, 1 to 3 wide at base. Mehlis' gland not observed. Seminal receptacle not observed. Laurer's canal not observed. Vitellarium comprising 2 lateral groups of 8 to 9 follicles at level of ovary; follicles 28 to 43 long, 22 to 29 wide, connecting as common vitelline duct, expanding to central, dorsal vitelline reservoir. Uterus voluminous, mostly intercecal, extending 38 to 67 (67) or $4 \%$ to $7 \%$ (5) of body length from posterior end to genital atrium, descending in coils dorso-sinistral to testis from region of female complex, reaching posterior coiling extent, ascending in coils ventrally, sinistral to testis, entering terminal organ ventrally, slightly anterior to mid-level; post-testicular uterus occupying 123 to 305 (305) or $63 \%$ to $87 \%$ (81\%) of post-testicular space, $14 \%$ to $28 \%$ (25\%) of body length. Eggs operculate, non-filamented, tanned, 13 to 20 long, 6 to 11 wide when distal.

Excretory vesicle I-shaped, extending to level of internal seminal vesicle, curving sinistrally around cirrus sac, often obscured by voluminous egg-filled uterus, one specimen containing 1 concretion; excretory pore terminal.

\subsubsection{Remarks}

Genolopa vesca n. sp. is most similar morphologically to G. ampullacea based on the presence, shape, and size of the genital atrium spines, size and shape of the terminal organ and cirrus spines, extent of the ceca, size and size ratios of the oral and ventral suckers, size of the pharynx, extent of the excretory vesicle, location and shape of the ovary and testis, and location of cecal bifurcation. Genolopa vesca n. sp. may be differentiated from G. ampullacea by the amount of post-testicular space $(22 \%$ to $32 \%$ ) in G. vesca n. sp. compared with the amount of post-testicular space ( $35 \%$ to $39 \%$ ) in G. ampullacea and the amount of post-testicular space occupied by the uterus relative to body length (14\% to $28 \%$ ) in G. vesca n. sp. compared with G. ampullacea ( $30 \%$ to $36 \%$ ). Additionally, the tegumental spines in the forebody ( 2 to 4 long, 1 to 3 wide at base) and hindbody ( 1 to 3 long, 2 to 3 wide at base) are smaller in G. vesca n. sp. compared with those in the forebody ( 4 to 6 long, 1 to 3 wide at base) and hindbody (3 to 4 long, 2 to 3 wide at base) in G. ampullacea.

Genolopa vesca n. sp. may be differentiated from G. plectorhynchi by the latter having bristle-like cirrus spines, a funnel-shaped oral sucker, a distinctly trilobed ovary, and larger eggs (26 to 29 long, 15 to 18 wide compared with 13 to 20 long, 6 to 11 wide). In addition, the illustration of the terminal genitalia of G. plectorhynchi appears to have spines in the genital atrium even though the presence of spines in the genital atrium was not stated in the description. The spines illustrated appear more similar in shape and size to those associated with the cirrus, so it is likely the spines in the genital atrium region in the illustration of G. plectorhynchi are from a partially extruded spiny cirrus.

Genolopa mugilis may be differentiated from $G$. vesca $\mathrm{n}$. sp. by the smaller sucker width ratio (1:0.53 to 1:0.58) in G. mugilis compared with the sucker width ratio (1:0.60 to 1:0.85) in G. vesca n. sp. and the smaller genital atrium spine size (7 to 13 long) in G. mugilis compared with the larger genital atrium spines (35 to 43 long, 2 to 4 wide at base) in G. vesca n. sp. The genital atrium spines of G. mugilis are more dispersed throughout the genital atrium and appear similar to the cirrus spines in size and shape (9 to 11 long), whereas the genital atrium spines of G. vesca n. sp. form a half ring-like structure of long bristles, near where the cirrus enters the genital atrium, that are distinct from the cirrus spines.

\subsection{Genolopa minuscula n. sp.}

\subsubsection{Taxonomic Summary}

Type host: Anisotremus surinamensis (Bloch, 1791), black margate, Haemulidae. Type locality: Marathon, Florida, USA $\left(24^{\circ} 41^{\prime} 58.2432^{\prime \prime} \mathrm{N}, 81^{\circ} 10^{\prime} 12.702^{\prime \prime} \mathrm{W}\right)$. 
Sites: intestine, pyloric ceca.

Specimens deposited: Holotype: USNM 1611641; 3 paratypes: USNM 1611642, 1611643, 16116443 hologenophores: USNM 1611645, 1611646, 1611647.

Sequences deposited: Partial 28S rDNA, 4 identical replicates (one submitted to GenBank: accession number MN984472); ITS2 rDNA, 1 sequence (one submitted to GenBank: accession number MN984473).

Etymology: The specific epithet is a Latin feminine adjective meaning somewhat less in reference to the less extensive uterus in this species compared with the type-species.

http://zoobank.org/urn:lsid:F9EA40EE-C8B4-42C2-B641-73297EEE6EE7

3.3.2. Description (Figure 3) (Based on 7 Gravid, Adult Specimens and 1 Non-Gravid Specimen, All Mounted without Pressure)

Body elongate, tapering slightly at both ends, widest near mid-body, 716 to 1373 (1356) long, 228 to 347 wide (335). Tegument spinose; spines larger and denser anteriorly, 4 to 6 long, 2 to 4 wide at base, smaller and less dense posteriorly, 2 to 3 long, 2 to 3 wide at base. Eyespot pigment absent. Oral sucker subspherical, subterminal, 76 to 103 (100) long or 7\% to 9\% (7) of body length, 78 to 107 (107) wide. Ventral sucker circular to subrounded, very weakly muscularized, near mid-body, 45 to 72 (64) long or $4 \%$ to $7 \%$ (4) of body length, 47 to 73 (73) wide. Sucker width ratio 1:0.57 to 1:0.79 (1:0.68). Forebody 296 to 614 (614) long or 30\% to 51\% (45\%) of body length; hindbody 320 to 696 (696) long or $43 \%$ to $60 \%$ (51\%) of body length. Pharynx slightly elongate to spherical, 46 to 61 (61) long or $4 \%$ to $6 \%$ (4) of body length, 40 to 54 (53) wide. Prepharynx slightly more than half length of pharynx to shorter. Esophagus length variable, 28 to 140 (111) long or 2\% to 11\% (8) of body length with cecal bifurcation closer to pharynx than ventral sucker, 134 to 284 (284) anterior to ventral sucker. Ceca extending well into hindbody, terminating 100 to 136 (124) from posterior end or $8 \%$ to $12 \%(9 \%)$ of body length.

Testis single, subglobular to irregular, median to submedian, dextral, 97 to 204 (204) long or $11 \%$ to $16 \%$ (15) of body length, 62 to 142 (118) wide. Post-testicular space 163 to 411 (411) long or 22\% to $31 \%(30 \%)$ of body length. Cirrus sac elongate, curving dextrally, dorsal to ventral sucker and ovary, terminating at level of or posterior to ovary, 156 to 299 (299) long or $16 \%$ to $27 \%$ (22) of body length, 54 to 90 (84) wide (contents consisting of internal seminal vesicle, pars prostatica, prostatic cells, and cirrus). Cirrus elongate, 78 to 141 long or $9 \%$ to $12 \%$ (everted in holotype) of body length, 24 to 45 wide when not everted, spined; spines not uniform in size with larger spines posteriorly and exteriorly, 10 to 15 long, 6 to 9 wide at base; smaller spines anteriorly and interiorly, 3 to 8 long, 2 to 4 wide at base. Seminal vesicle internal, unipartite, elongate, in posterior region of cirrus sac, 34 to 122 (122) long or $5 \%$ to $10 \%$ (9) of body length, 25 to 71 (60) wide. Genital atrium spined; spines 28 to 36 long, 3 to 4 wide at base when cirrus not everting into genital atrium, more numerous than shown in Figure 3a,b. Genital pore median, 7 to 21 anterior to ventral sucker.

Ovary subglobular to triangular, never distinctly lobed, submedian, dextral, pre-testicular or slightly overlapping anterior of testis, 33 to 106 (83) long or 5\% to 8\% (6) of body length, 45 to 105 (97) wide. Terminal organ subarcuate, conspicuous, bipartite, sinistral to cirrus sac, 112 to 146 (146) long or $11 \%$ to $14 \%$ (11) of body length, 56 to 78 (64) wide; posterior portion muscular, unspined, blind; anterior region separated by a muscular sphincter, opening into genital atrium, spined; spines uniformly spaced, 8 to 15 long, 1 to 2 wide at base. Mehlis' gland and female complex not observed. Seminal receptacle not observed. Laurer's canal opening dorsally, at ovarian level, dextral to ovary (observed in only one specimen). Vitellarium consisting of 2 lateral groups of 6 to 9 follicles at ovarian level; follicles 24 to 59 long, 14 to 40 wide, smaller in younger individuals, connecting with dorsal, common lateral duct, expanding dorsally as vitelline reservoir. Uterus voluminous, mostly intercecal, extending 98 to 202 (146) or $8 \%$ to $18 \%$ (11) of body length from posterior end to genital atrium, descending in coils from ovarian level, dorso-sinistral to testis, reaching posterior extent, ascending in coils ventrally, sinistral to testis, joining with terminal organ near mid-level; post-testicular uterus occupying 101 to 277 (264) or 
$41 \%$ to $76 \%$ (64) of post-testicular space, $12 \%$ to $21 \%$ (19) of body length. Eggs 14 to 23 long, 8 to 12 wide, typically 17 to 20 long, 9 to 11 wide when distal.

Excretory vesicle I-shaped, extending to ovarian level to posterior end of ventral sucker, occasionally curved in anterior half, usually obscured by eggs; excretory pore terminal.

\subsubsection{Remarks}

Genolopa minuscula n. sp. is most morphologically similar to G. vesca n. sp. and G. ampullacea. Similarities among the species include ovary and testis size, shape, location, the presence, size, and shape of the genital atrium spines, the size and shape of spines in the terminal organ, extension of the ceca well into the hindbody, extension of the excretory vesicle to the ovarian level or posterior edge of ventral sucker, and the oral sucker and ventral sucker size width ratios.

Genolopa minuscula n. sp. may be differentiated from G. vesca n. sp. by the latter having smaller tegumental spines in the forebody ( 2 to 4 long, 1 to 3 wide at base) and hindbody ( 1 to 3 long, 2 to 3 wide at base) compared with the size of tegumental spines in the forebody ( 4 to 6 long, 2 to 4 wide at base) and hindbody (2 to 3 long, 2 to 3 wide at base) of G. minuscula n. sp.

Genolopa minuscula n. sp. may be differentiated from G. vesca n. sp. and G. ampullacea by the slightly larger pharynx (46 to 61 long, 40 to 54 wide) and the slightly larger size of the "large" spines on the cirrus (10 to 15 long, 6 to 9 wide at base) in G. minuscula n. sp. compared with the pharynx (34 to 43 long, 33 to 40 wide) and "large" cirrus spines (6 to 9 long, 5 to 7 wide) in G. vesca n. sp. and compared with the pharynx ( 36 to 40 long, 29 to 27 wide) and "large" cirrus spines ( 8 to 12 long, 3 to 7 wide at base) in G. ampullacea.

Genolopa minuscula n. sp. may be further differentiated from G. ampullacea by the amount of post-testicular space ( $22 \%$ to $31 \%$ ) in G. minuscula n. sp. compared with the space (35\% to $39 \%$ ) in G. ampullacea, the amount of post-testicular space occupied by the uterus relative to body length $(12 \%$ to $21 \%$ ) in G. minuscula n. sp. compared with the post-testicular space occupied by the uterus relative to body length (30\% to $36 \%$ ) in G. ampullacea, and the amount of post-testicular space occupied by the uterus relative to post-testicular space $(41 \%$ to $76 \%$ ) in G. minuscula n. sp. compared with the post-testicular space occupied by the uterus relative to post-testicular space ( $83 \%$ to $92 \%$ ) in G. ampullacea; all three features are relatively reduced in G. minuscula n. sp. compared with G. ampullacea.

Genolopa minuscula n. sp. may be differentiated from G. plectorhynchi by the latter having a funnel-shaped oral sucker, a distinctly trilobed ovary, larger eggs (26 to 29 long, 15 to 18 wide compared with 14 to 23 long, 8 to 12 wide), bristle-like spines on the cirrus, and no mention of a spiny genital atrium. However, the illustration of the terminal genitalia of G. plectorhynchi appears to have spines surrounding the genital atrium, but these spines appear to more closely resemble cirrus spines in shape and size. It is possible that the spines near the genital atrium in the illustration are from a partially extruded cirrus.

Genolopa mugilis may be differentiated from G. minuscula n. sp. by the smaller size of the genital atrium spines (7 to 13 long) that are more evenly, widely dispersed throughout the whole genital atrium in G. mugilis compared with the larger genital atrium spines (28 to 36 long, 3 to 4 wide) that form a half ring-like structure of long bristles near where the cirrus enters the genital atrium in $G$. minuscula $\mathrm{n}$. sp. The range of the sucker width ratios slightly overlaps between G. minuscula $\mathrm{n}$. sp. (1:0.57 to 1:0.79) and G. mugilis (1:0.53 to 1:0.58). 
a

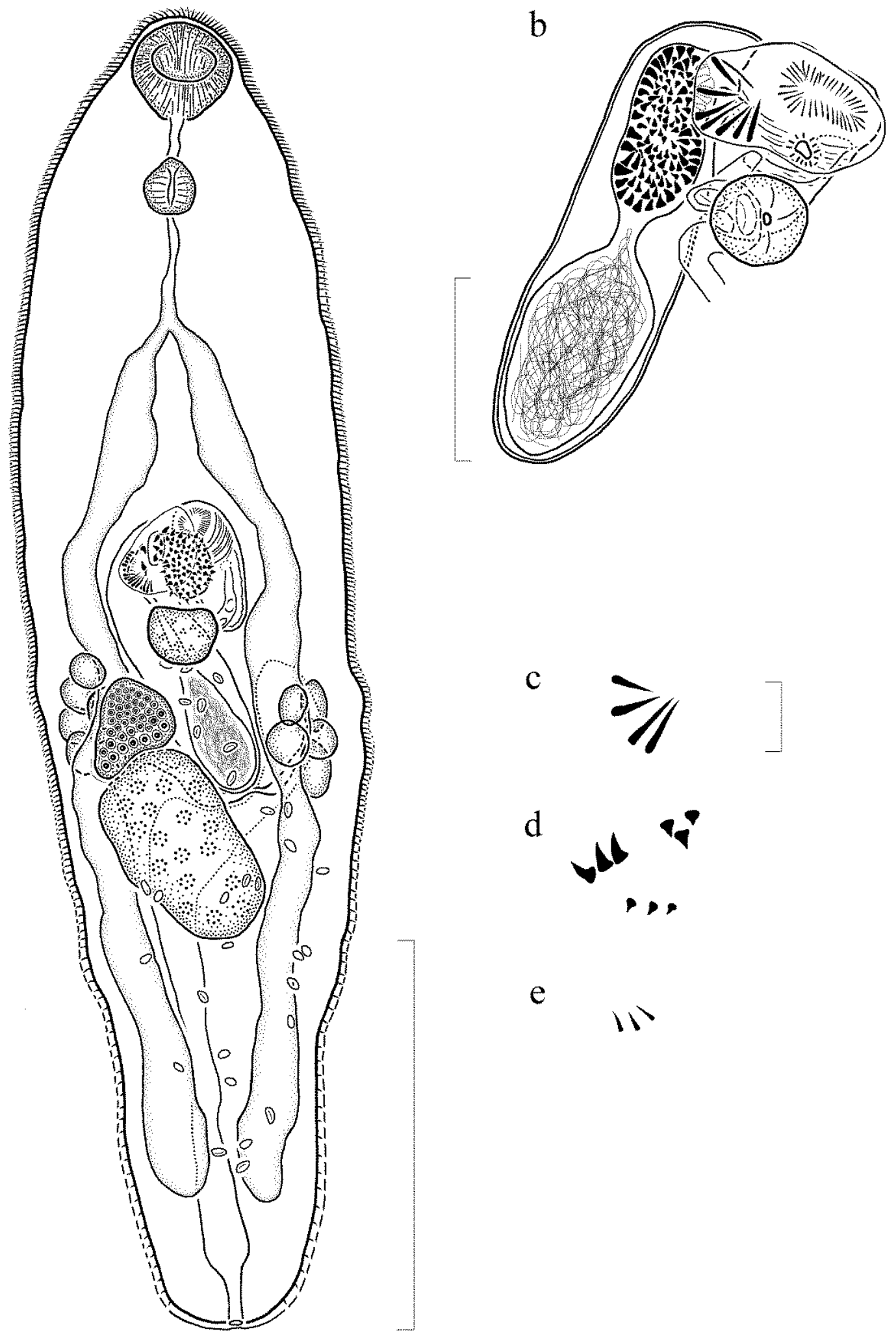

Figure 3. Genolopa minuscula n. sp. from Anisotremus surinamensis. (a) Ventral view, holotype, scale bar $400 \mu \mathrm{m}$, note cirrus everted; (b) ventral view, terminal genitalia, scale bar $100 \mu \mathrm{m}$, note anterior portion of terminal organ is a cross sectional view; (c) genital atrium spines, scale bar $40 \mu \mathrm{m}$; (d) cirrus spines, note the different sized spines, scale bar $40 \mu \mathrm{m}$; (e) anterior terminal organ spines, scale bar $40 \mu \mathrm{m}$. 


\subsection{Molecular Results}

The trimmed multiple sequence alignment length of partial 28S rDNA fragments consisted of 1163 base pairs, including gaps. Masking revealed no ambiguous column, i.e., columns with confidence scores below the cut off value of 0.413 , so no column was excluded in the phylogenetic analysis. $\mathrm{BI}$ analysis resulted in an estimated phylogeny (Figure 4) that is consistent with previously reported monorchiid phylogenies $[14,21,39]$. The present phylogeny indicates that the included species of Genolopa (all from western Atlantic Ocean) form a well-supported clade with P. orthopristis (Appendix A). This clade is separate from any species of Lasiotocus, Parachrisomon, or Proctotrema.

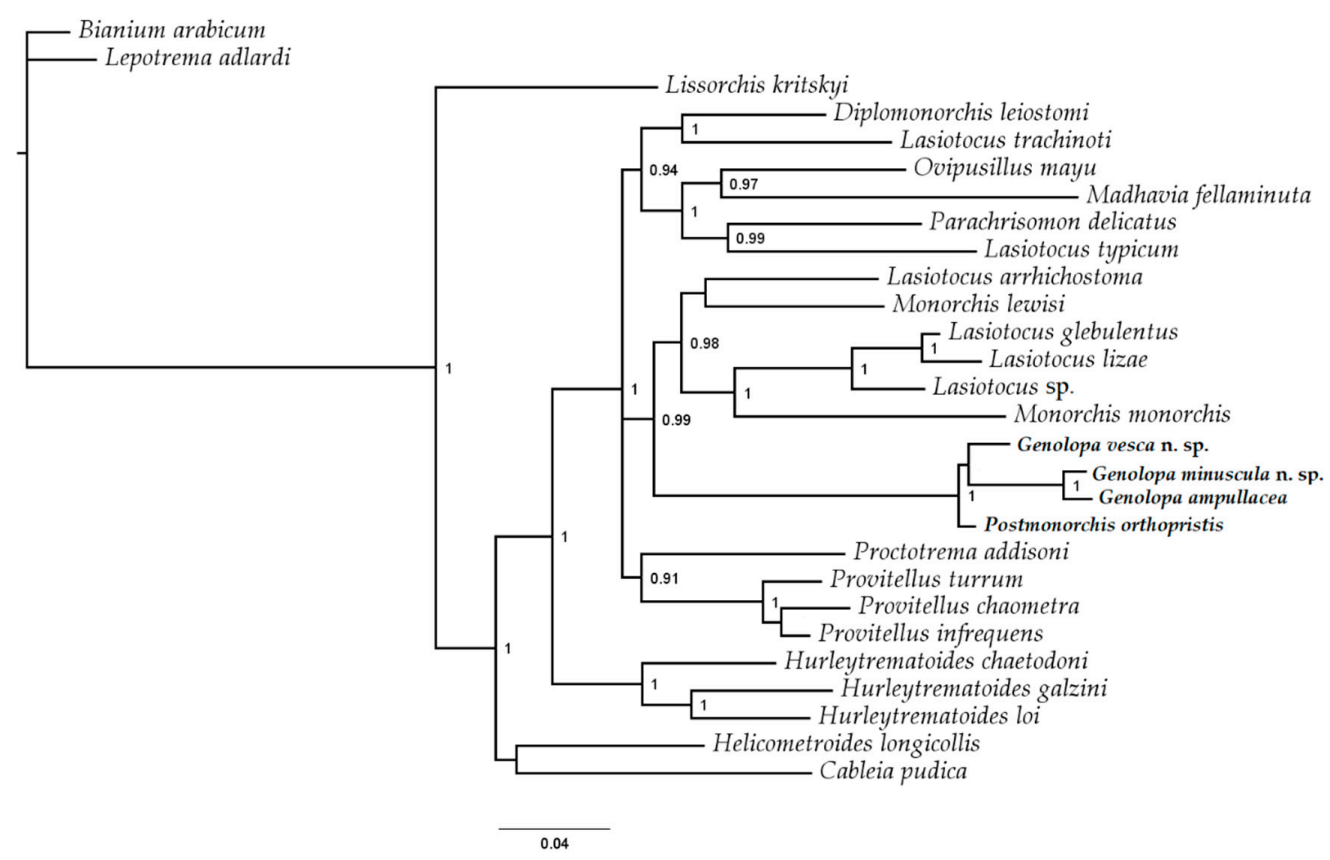

Figure 4. Interrelationships among members of the Monorchiidae based on Bayesian inference analysis of partial 28S rDNA data. Bayesian inference posterior probabilities are shown at the nodes; support values $<0.85$ are not shown. Genolopa-Postmonorchis clade highlighted with bold text.

Importantly, the present phylogeny supports that Genolopa is a distinct lineage from Lasiotocus, Parachrisomon, and Proctotrema at the generic level. Pairwise comparisons of variable sites of the $28 \mathrm{~S}$ rDNA gene among species of Genolopa and Postmonorchis are presented in Table 3. Sequences of G. minuscula n. sp. and G. ampullacea differed by $1.6 \%$ (19 bp). Sequences of G. vesca n. sp. and both G. minuscula n. sp. and G. ampullacea differed by $4.9 \%$ (57 bp). The sequence of P. orthopristis differed the least with G. vesca n. sp. by $2.1 \%$ (24 bp). Sequences of P. orthopristis and G. minuscula n. sp. differed by $3.9 \%$ ( $45 \mathrm{bp}$ ), and sequences of P. orthopristis and G. ampullacea differed by $4 \%$ (47 bp).

Table 3. Pairwise comparison among partial fragments ( 1163 base pairs long) of $28 \mathrm{~S}$ rDNA from species of Genolopa and Postmonorchis in present study, shown as number of variable sites with (\%) (above diagonal).

\begin{tabular}{lllll}
\hline Species & G. minuscula & G. ampullacea & G. vesca & P. orthopristis \\
\hline P. orthopristis & $45(3.9)$ & $47(4.0)$ & $24(2.1)$ & - \\
G. minuscula & - & $19(1.6)$ & $57(4.9)$ & - \\
G. ampullacea & & - & $57(4.9)$ & - \\
G. vesca & & & - & - \\
\hline
\end{tabular}

The present phylogeny does not support a distinction between Genolopa and Postmonorchis, suggesting the two genera do not represent distinct generic lineages or more taxa are necessary to elucidate this relationship. The Genolopa-Postmonorchis clade is closely affiliated with a clade consisting 
of species of Monorchis Monticelli, 1893 and some species of Lasiotocus. We also provide sequence data for three species of Lasiotocus that had no prior sequence data available (Appendix A). These new data further support that Lasiotocus is polyphyletic but at least some species of Lasiotocus are closely related to Monorchis [21].

\section{Discussion}

The estimated phylogeny of the Monorchiidae (Figure 4) was constructed using publicly available partial $28 \mathrm{~S}$ rDNA sequence data from all genera thus far plus new material supported by vouchers; it also includes taxa from the Indo-Pacific Ocean, Mediterranean Sea, North Sea, and western Atlantic Ocean. Prior to the present study, molecular data were available for only two monorchiid species from the northwestern Atlantic Ocean: Diplomonorchis leiostomi Hopkins, 1941 and Hurlytrematoides chaetodoni (Manter, 1942) Yamaguti, $1954[17,24]$. This study contributed novel molecular data from six additional northwestern Atlantic Ocean monorchiid species in three genera. The novel molecular data from Genolopa spp. represent the first such available data for the genus, and novel molecular data from Lasiotocus spp. represent the first sequence data available from northwestern Atlantic species of that genus. As expected, the northwestern Atlantic species of Lasiotocus herein included did not represent a natural group as is apparent in this genus from other studies [14,21,39]; taxonomic and systematic problems among species of Lasiotocus will be the focus of a separate paper.

Interestingly, the novel molecular data from P. orthopristis does not represent the first available data for the genus; however, we disagree with the generic classification of these sequences (GenBank accession no. KC603478 [58] and MF374321 [59]) because one classification was made using the BLASTn tool with no morphological evidence derived from adult vouchers (MF374321), and the other was based on morphological examination of metacercariae, in which some of the key diagnostic features for Postmonorchis (uterus location and extent, spined cirrus, anteriorly spined terminal organ) are not yet manifested (KC603478). The two molecular data for Postmonorchis are publicly available partial $18 \mathrm{~S}$ rDNA, complete ITS1, 5.8S rDNA, and ITS2, and partial 28S rDNA sequences. One is derived from metacercariae collected from the wedge clam in Italy (KC603478) [58], and the second is derived from the tissue of the European flat oyster in Italy (MF374321) [59]. The ITS2 sequences from both studies are identical; however, the published partial $28 \mathrm{~S}$ rDNA sequences were too short to include with our analysis. We conducted a pairwise comparison of the ITS2 sequences from Postmonorchis sp. (KC603478) and our P. orthopristis material; there was a $26 \%$ bp difference between the two, suggesting Postmonorchis sp. (KC603478) is not actually a species in Postmonorchis. Our data are from morphologically identified adult material whereas Postmonorchis sp. (KC603478) data are based on metacercariae. This unidentified species may be included in analyses of the Monorchiidae once more ITS2 and $28 \mathrm{~S}$ rDNA sequences become available.

The presented phylogeny provides evidence suggesting Genolopa represents a distinct evolutionary lineage that is closely related to Postmonorchis and distinct from Parachrisomon, Proctotrema, and Lasiotocus, three genera to which Genolopa is morphologically similar and that have available molecular data [14-17]. Similar to previous analyses, Lasiotocus is polyphyletic [14,21,39]. The present study contributed data from the type-species for Genolopa and Postmonorchis, but unfortunately, no molecular data are yet available from the type-species for Parachrisomon, Proctotrema, or Lasiotocus. Sequence data from the type-species is needed to determine the true lineage of Lasiotocus. We made several attempts to collect Lasiotocus mulli (Stossich, 1883) Odhner, 1911 (type-species) but were unsuccessful. Ferrer-Maza et al. [60] represents the most recent report of L. mulli collected in the Mediterranean Sea, but personal communication with the primary author revealed that the prevalence of L. mulli was very low in her study. Over 300 specimens of the definitive host were examined, and only 5 specimens of L. mulli were found.

The absence of molecular data from type-species for these related genera prevent us from making serious inferences regarding interrelationships among these five morphologically similar genera. Nevertheless, the novel molecular data from Genolopa spp. serve to confirm that the primary diagnostic 
features for the genus (the presence of spines in the genital atrium along with the presence of a bipartite, anteriorly spined terminal organ), as proposed by Manter [8], serve reliably. Species in Proctotrema do not have spines in the genital atrium, and they have a unipartite terminal organ. Species in both Lasiotocus and Parachrisomon do not have spines in the genital atrium, and species in Parachrisomon, uniquely among these morphologically similar genera, have a vitellarium distributed well into the hindbody [1].

Despite the close similarity and phylogenetic relationship exhibited between Genolopa and Postmonorchis, there are several obvious morphologic differences between the genera ([1,20], present study). Species of Postmonorchis are smaller and oval compared with species of Genolopa that are larger and elongate. The uterus is mostly intercecal, with portions overlapping the ceca, with only a small portion extending into extracecal space in species of Genolopa, whereas the uterus is mostly extracecal and overlapping the ceca with only a small portion extending into the intercecal space in species of Postmonorchis. Furthermore, the uterus extends from the cecal bifurcation to the testis, not posterior to the testis, in species of Postomonorchis, but the uterus extends from the genital pore to posterior to the testis in species of Genolopa. The size of the cirrus sac is larger relative to body size in species of Postmonorchis (approximately 1/3 body size) compared with that in species of Genolopa. The testis is located at the posterior end in species of Postmonorchis but is located more medially in species of Genolopa. Finally, and perhaps most importantly, species of Genolopa have spines in the genital atrium whereas species of Postmonorchis do not have spines in the genital atrium based on the original generic description and the description of the type-species by Hopkins [11].

We accept Genolopa as a valid genus based on the evidence provided in this study. Genolopa currently contains 13 nominal species (Table 4). However, the authorities for only 3 of the 13 species attempted to discuss or illustrated the presence of spines in the genital atrium in conjuction with an anteriorly spined, bipartite terminal organ in original descriptions: G. ampullacea, G. plectorhynchi, and G. mugilis $[8,56,61]$. Therefore, tentatively we do not agree with the placement of the other nominal species in Genolopa and consider them to be incertae sedis with a few violating the diagnosis of the family. The type materials from these species should be reexamined to determine whether genital atrium spines are present and if the terminal organ is bipartiate and spined anteriorly to confirm if these species represent acceptable species of Genolopa. The genital atrium spines described or illustrated in G. plectorhynchi, G. brevicaecum and G. mugilis resemble cirrus spines in size and shape. Consequently, type materials of G. plectorhynchi, G. brevicaecum and G. mugilis should also be examined to clarify if the genital atrium spines are from a partially extruded cirrus or are in fact spines associated with the genital atrium. Moreover, representatives of these confounding species should be sequenced to verify their generic status.

Table 4. Nominal species of Genolopa.

\begin{tabular}{|c|c|}
\hline Species & Authority \\
\hline Genolopa ampullacea * & Linton, 1910 \\
\hline Genolopa anisotremi $i^{* *}$ & (Nahhas and Cable, 1964) Yamaguti, 1971 \\
\hline Genolopa brevicaecum ** & (Manter, 1942) Manter and Pritchard, 1961 \\
\hline Genolopa bychowskii ** & Zhukov, 1977 \\
\hline Genolopa cheilini ** & Nagaty and Abdel-Aal, 1972 \\
\hline Genolopa loborchis ** & Wang, 1977 \\
\hline Genolopa lunulata ** & Nagaty and Abdel-Aal, 1972 \\
\hline Genolopa magnacirrus ** & Thatcher, 1996 \\
\hline Genolopa microsoma ** & Lebedev, 1968 \\
\hline Genolopa mintungensis ** & Wang, 1975 \\
\hline Genolopa mugilis & Knoff and Amato, 1992 \\
\hline Genolopa plectorhynchi & (Yamaguti, 1934) Hopkins, 1941 \\
\hline Genolopa pritchardae ${ }^{* *}$ & (Nahhas and Cable, 1964) Yamaguti, 1971 \\
\hline
\end{tabular}


Investigation of type material for Genolopa longicaudata Siddiqi and Cable, 1960 is also needed to clarify the validity of this species or its synonymy with G. ampullacea. Siddiqi and Cable [62] described G. longicaudata and differentiated it from G. ampullacea based on the post-testicular space and length of the terminal organ. We do not believe these are the appropriate features to use to distinguish the two species, if indeed they represent two species, because these features can exhibit high levels of variability in monorchiids. At present, we tentatively accept the validity of G. longicaudata because we believe hindbody size and a more anteriorly located ventral sucker (based on observations of illustrations and scale measurements by Siddiqi and Cable [62]) serve to better differentiate G. longicaudata. Forebody and hindbody lengths are $18.7 \%$ and $77 \%$ of overall body length, respectively, in the illustration of G. longicaudata, or close to one fifth of the body length. Siddiqi and Cable [62] stated that the ventral sucker of $G$. longicaudata is approximately one fifth the body length from the anterior end. Our observations of forebody and hindbody lengths of G. ampullacea range from $29-36 \%$ and $57-65 \%$ of body length, respectively (based on measurements of the type material and our newly collected material). The ventral sucker of G. ampullacea is located at approximately the anterior one third of the body length [8], showing these metrics are quite different between the species.

It is very difficult to decide on the validity of G. ampullacea from other reports without those reports having extensive descriptions, and very few do this; also, there is a need for molecular data. Many of these reports are not taxonomic papers; many are parasite community investigations of hosts from specific locations. No information about G. ampullacea other than host is provided in the reports by Manter [43], Sogandares-Bengal [45], Nahhas and Cable [46], Rees [47], Fischthal [49], Centeno and Bashirullah [51], and Bashirullah and Díaz [52]. The hosts listed from those reports (various grunt species) are like those of accurately identified specimens of G. ampullacea; however, without any additional information, we do not know if they are accurate identifications. Overstreet [63] noted some slight differences between his specimens of G. ampullacea and those by earlier works such as mostly smaller eggs, a distinctly trilobed ovary, and a pyriform oral sucker, but without a more detailed description of his specimens and molecular data, we are not sure if this is a valid report of G. ampullacea. Lozano et al. [64] reported G. ampullacea from the Iberian Peninsula (new location) and a similar host species (another grunt), but the few measurements provided, such as body size, pharynx size, and cirrus sac size, are much larger indicating that these specimens are likely not $G$. ampullacea. The specimens of G. ampullacea described from Mosquera et al. [65] had a distinctly trilobed ovary and much larger genital atrium spines suggesting they are likely not G. ampullacea.

To summarize, Genolopa has been provisionally considered synonymous with other genera (Lasiotocus, Proctotrema, Parachrisomon, Proctotrematoides, Paraproctotrema, and Monorchicestrahelmins) based on incomplete morphological data regarding terminal genitalia spination available for material. Our phylogenetic analysis indicates that Genolopa likely represents a distinct lineage from those genera and is closely related to Postmonorchis, a genus ironically with which it has not been confused or associated as a close relative due to several distinct morphological differences. Therefore, like Madhavi [1], we agree with Manter [8] in believing that the combination of spines in the genital atrium and a bipartite, anteriorly spined terminal organ represent cornerstones for the generic diagnosis of Genolopa. We also acknowledge the need for morphologic investigation of the other species of Genolopa considered incertae sedis and the need for additional molecular data to determine if these features consistently determine species of Genolopa or possibly just form a western Atlantic clade and to better clarify interrelationships within the Monorchiidae.

Supplementary Materials: The following are available online at http://www.mdpi.com/1424-2818/12/2/51/s1.

Author Contributions: Conceptualization, A.J.P., S.S.C. and R.M.O.; methodology, A.J.P., S.S.C. and R.M.O.; formal analysis, A.J.P. and S.S.C.; investigation, A.J.P. and S.S.C.; resources, R.M.O.; data curation, A.J.P.; writing-original draft preparation, A.J.P.; writing-review and editing, A.J.P., S.S.C. and R.M.O.; visualization, R.M.O.; supervision, R.M.O.; project administration, A.J.P.; funding acquisition, A.J.P. and R.M.O. All authors have read and agreed to the published version of the manuscript. 
Funding: This research was funded in part by a grant from BP Exploration and Production, Inc. for R.M.O. It was also funded in part by the Robin M. Overstreet Coastal Sciences Endowment through The University of Southern Mississippi received by A.J.P. in 2017 and 2018. Some of the fish hosts were collected pursuant to FL SAL-16-0942-SR.

Acknowledgments: We would like to thank C. Hubbard; A. Claxton; A. Kuhn, N. Dix and the Guana Tolomato Matanzas National Estuarine Research Reserve (GTM NERR); and M. Sullivan, his undergraduate students, and the staff of the Marine Field Station at Stockton University for field assistance. We thank V. Tkach, J. Jovonovich Alvillar, J. Wright, and B. Jones for assistance with the molecular aspects of data collection. We also thank M. Andres for initial feedback on the manuscript structure, input on phylogenetic analysis techniques, and assistance with GenBank submissions, A. Phillips and A. Robinson for loaning type and voucher specimens, and A. Phillips and K. Ahlfeld for providing museum accession numbers.

Conflicts of Interest: The authors declare no conflict of interest. The funders had no role in the design of the study; in the collection, analyses, or interpretation of data; in the writing of the manuscript; or in the decision to publish the results.

\section{Appendix A}

\section{Supplemental Molecular Data}

Postmonorchis orthopristis Hopkins, 1941.

Host: Haemulon flavolineatum Desmarest, 1823, French grunt, Haemulidae.

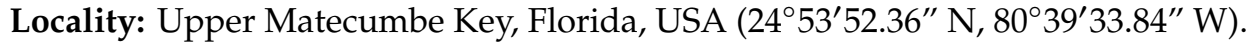

Site: intestine.

Specimens deposited: USNM 1611660, 1611661 (2 vouchers); USNM 1611659 (1 hologenophore).

Sequences deposited: Partial 28S rDNA, 2 replicates, one hologenophore, one paragenophore, (hologenophore submitted to GenBank: accession number MN984475); ITS2 rDNA, one hologenophore (submitted to GenBank: accession number MN984475).

Remarks: Our specimens agree well with the description by Hopkins (1941).

Lasiotocus trachinoti Overstreet and Brown, 1970.

Host: Trachinotus carolinus Linnaeus, 1766, Florida pompano, Carangidae.

Locality: Jacksonville, Florida, USA $\left(30^{\circ} 01^{\prime} 25.8^{\prime \prime} \mathrm{N}, 81^{\circ} 19^{\prime} 21.9^{\prime \prime} \mathrm{W}\right)$.

Sites: intestine, pyloric ceca.

Specimens deposited: USNM 1611664, 1611665, 1611666 (3 vouchers).

Sequences deposited: All paragenophores; partial 28S rDNA, 6 replicates (one submitted to GenBank accession number MN984478); ITS2 rDNA, 6 replicates (one submitted to GenBank: accession number MN984478).

Remarks: Our specimens agree well with the description by Overstreet and Brown [66].

Lasiotocus glebulentus Overstreet, 1971.

Host: Mugil curema Valenciennes, 1836, white mullet, Mugilidae.

Locality: Beaufort, North Carolina, USA ( $\left.34^{\circ} 41^{\prime} 03.5^{\prime \prime} \mathrm{N}, 76^{\circ} 31^{\prime} 42.7^{\prime \prime} \mathrm{W}\right)$.

Sites: intestine.

Specimens deposited: USNM 1611662, 1611663 ( 2 vouchers).

Sequences deposited: All paragenophores; partial 28S rDNA, 4 replicates (one submitted to GenBank: accession number MN984476).

Remarks: Our specimens agree well with the description by Overstreet [27].

\section{Lasiotocus sp. unidentified}

Host: Menidia menidia Linnaeus, 1766, Atlantic silverside, Atherinopsidae.

Locality: Great Bay Estuary, New Jersey, USA ( $39^{\circ} 31^{\prime} 11.0^{\prime \prime}$ N, $74^{\circ} 21.08 .1^{\prime \prime}$ W).

Sequences deposited: Partial 28S rDNA, 2 replicates (one submitted to GenBank: accession number MN984477).

Remarks: Our specimens were in a condition too poor for species-level identification. 


\section{References}

1. Madhavi, R. Family Monorchiidae Odhner, 1911. In Keys to the Trematoda; Bray, R.A., Gibson, D.I., Jones, A., Eds.; CAB International and Natural History Museum: Cambridge, MA, USA, 2008; pp. 145-175. ISBN 978.

2. Yamaguti, S. A synoptical review of the life histories of digenetic trematodes of vertebrates, 1st ed.; Yugaku-Sha, Ltd.: Tokyo, Japan, 1975.

3. Gilardoni, C.; Carballo, M.C.; Cremonte, F. The life cycle and geographical distribution of the monorchiid Proctotrema bartolii (Digenea) in the clam Darina solenoides from the Patagonian coast, Argentina. J. Helminthol. 2013, 87, 392-399. [CrossRef]

4. Bartoli, P.; Jousson, O.; Russell-Pinto, F. The life cycle of Monorchis parvus (Digenea: Monorchiidae) demonstrated by developmental and molecular data. J. Parasitol. 2000, 86, 479-489. [CrossRef]

5. Young, R.T. Postmonorchis donacis, a new species of monorchid trematode from the Pacific coast, and its life history. J. Wash. Acad. Sci. 1953, 43, 88-93.

6. Bagnato, E.; Gilardoni, C.; Pina, S.; Rodrigues, P.; Cremonte, F. Redescription and life cycle of the monorchiid Postmonorcheides maclovini Szidat, 1950 (Digenea) from the Southwestern Atlantic Ocean: morphological and molecular data. Parasitol. Int. 2016, 65, 44-49. [CrossRef]

7. Manter, H.W. Some digenetic trematodes of marine fishes of Beaufort, North Carolina. Parasitology 1931, 23, 396-411. [CrossRef]

8. Manter, H.W. Monorchiidae (Trematoda) from fishes of Tortugas, Florida. Trans. Am. Microsc. Soc. 1942, 61, 349-360. [CrossRef]

9. Manter, H.W.; Pritchard, M.H. Studies on the digenetic trematodes of Hawaiian fishes: families Monorchiidae and Haploporidae. J. Parasitol. 1961, 47, 483-492. [CrossRef]

10. Thomas, J.D. Trematodes of Ghanian sub-littoral Fishes. I. The Family Monorchiidae. J. Parasitol. 1959, 45, 95-113. [CrossRef]

11. Hopkins, S.H. New genera and species of the family Monorchiidae (Trematoda), with a discussion of the excretory system. J. Parasitol. 1941, 27, 395-407. [CrossRef]

12. Yamaguti, S. Synopsis of Digenetic Trematodes of Vertebrates; Keigaku: Tokyo, Japan, 1971.

13. Machida, M. Monorchiidae (Trematoda, Digenea) from fishes of Japanese and adjacent Waters. Bull. Natl. Sci. Mus. Tokyo Ser. A Zool. 2005, 31, 123-136.

14. Wee, N.Q.X.; Cutmore, S.C.; Cribb, T.H. Two monorchiid species from the freckled goatfish, Upeneus tragula Richardson (Perciformes: Mullidae), in Moreton Bay, Australia, including a proposal of a new genus. Syst. Parasitol. 2018, 95, 353-365. [CrossRef]

15. Searle, E.L.; Cutmore, S.C.; Cribb, T.H. Monorchiid trematodes of the painted sweetlips, Diagramma labiosum (Perciformes: Haemulidae), from the southern Great Barrier Reef, including a new genus and three new species. Syst. Parasitol. 2014, 88, 195-211. [CrossRef]

16. Atopkin, D.M.; Besprozvannykh, V.V.; Ngo, H.D.; Van Ha, N.; Van Tang, N.; Ermolenko, A.V.; Beloded, A.Y. Morphometric and molecular data of the two digenean species Lasiotocus lizae Liu, 2002 (Monorchiidae) and Paucivitellosus vietnamensis sp. n. (Bivesiculidae) from mullet fish in Tonkin Bay, Vietnam. J. Helminthol. 2017, 91, 346-355. [CrossRef]

17. Olson, P.D.; Cribb, T.H.; Tkach, V.V.; Bray, R.A.; Littlewood, D.T.J. Phylogeny and classification of the Digenea (Platyhelminthes: Trematoda). Int. J. Parasitol. 2003, 33, 733-755. [CrossRef]

18. McNamara, M.K.A.; Miller, T.L.; Cribb, T.H. Evidence for extensive cryptic speciation in trematodes of butterflyfishes (Chaetodontidae) of the tropical Indo-West Pacific. Int. J. Parasitol. 2014, 44, 37-48. [CrossRef]

19. Tkach, V.V.; Pawlowski, J.; Mariaux, J.; Swiderski, Z. Molecular phylogeny of the suborder Plagiorchiata and its position in the system of Digenea. In Interrelationships of the Platyhelminthes; Littlewood, D.T.J., Bray, R.A., Eds.; Taylor \& Francis: London, UK, 2001; pp. 186-193.

20. Jousson, O.; Bartoli, P.; Pawlowski, J. Cryptic speciation among intestinal parasites (Trematoda: Digenea) infecting sympatric host fishes (Sparidae). J. Evol. Biol. 2000, 13, 778-785. [CrossRef]

21. Cribb, T.H.; Wee, N.Q.X.; Bray, R.A.; Cutmore, S.C. Monorchis lewisi n. sp. (Trematoda: Monorchiidae) from the surf bream, Acanthopagrus australis (Sparidae), in Moreton Bay, Australia. J. Hazard. Mater. 2018, 92, 100-108. [CrossRef] 
22. Bray, R.A.; Palm, H.W.; Cutmore, S.C.; Cribb, T.H. Three members of Opisthomonorcheides Parukhin, 1966 (Digenea: Monorchiidae) from carangid fishes (Perciformes) from Indonesia, with a review of the genus. Syst. Parasitol. 2017, 94, 443-462. [CrossRef]

23. Bagnato, E.; Gilardoni, C.; Di Giorgio, G.; Cremonte, F. A checklist of marine larval trematodes (Digenea) in molluscs from Argentina, Southwestern Atlantic coast. J. Biodivers. Data 2015, 11, 1-10. [CrossRef]

24. Andres, M.J.; Pulis, E.E.; Curran, S.S.; Overstreet, R.M. On the systematics of some marine haploporids (Trematoda) with the description of a new species of Megasolena Linton, 1910. Parasitol. Int. 2018, 67, 805-815. [CrossRef]

25. Cribb, T.H.; Bray, R.A. Gut wash, body soak, blender and heat-fixation: approaches to the effective collection, fixation and preservation of trematodes of fishes. Syst. Parasitol. 2010, 76, 1-7. [CrossRef]

26. Curran, S.S.; Overstreet, R.M.; Tkach, V.V. Phylogenetic affinities of Plagiocirrus Van Cleave and Mueller, 1932 with the description of a new species from the Pascagoula River, Mississippi. J. Parasitol. 2007, 93, 1452-1458. [CrossRef]

27. Overstreet, R.M. Some adult digenetic trematodes in striped mullet from the Northern Gulf of Mexico. J. Parasitol. 1971, 57, 967-974. [CrossRef]

28. Pleijel, F.; Jondelius, U.; Norlinder, E.; Nygren, A.; Oxelman, B.; Schander, C.; Sundberg, P.; Thollesson, M. Phylogenies without roots? A plea for the use of vouchers in molecular phylogenetic studies. Mol. Phylogenet. Evol. 2008, 48, 369-371. [CrossRef]

29. Tkach, V.V.; Snyder, S.D. Aptorchis megacetabulus n. sp. (Platyhelminthes: Digenea) from the northern long-necked turtle, Chelodina rugosa (Pleurodira: Chelidae), in Australia. J. Parasitol. 2007, 93, 404-408. [CrossRef]

30. Curran, S.S.; Tkach, V.V.; Overstreet, R.M. A review of Polylekithum Arnold, 1934 and its familial affinities using morphological and molecular data, with description of Polylekithum catahoulensis sp. nov. Acta Parasitol. 2006, 51, 238-248. [CrossRef]

31. Littlewood, D.T.J. Molecular phylogenetics of cupped oysters based on Partial $28 \mathrm{~S}$ rRNA Gene Sequences. Mol. Phylogenet. Evol. 1994, 3, 221-229. [CrossRef]

32. Keller, A.; Schleicher, T.; Schultz, J.; Müller, T.; Dandekar, T.; Wolf, M. 5.8S-28S rRNA interaction and HMM-based ITS2 annotation. Gene 2009, 430, 50-57. [CrossRef]

33. Ankenbrand, M.J.; Keller, A.; Wolf, M.; Schultz, J.; Förster, F. ITS2 database V: Twice as much. Mol. Biol. Evol. 2015, 32, 3030-3032. [CrossRef]

34. Sela, I.; Ashkenazy, H.; Katoh, K.; Pupko, T. Guidance 2: Accurate detection of unreliable alignment regions accounting for the uncertainty of multiple parameters. Nucleic Acids Res. 2015, 43, W7-W14. [CrossRef]

35. Landan, G.; Graur, D. Local reliability measures from sets of co-optimal multiple sequence alignments. In Proceedings of the Pacific Symposium on Biocomputing, Kohala Coast, HI, USA, 4-8 January 2008; pp. 15-24.

36. Huelsenbeck, J.P.; Ronquist, F. MRBAYES: Bayesian inference of phylogenetic trees. Bioinform. Appl. Note 2001, 17, 754-755. [CrossRef]

37. Ronquist, F.; Teslenko, M.; Van Der Mark, P.; Ayres, D.L.; Darling, A.; Höhna, S.; Larget, B.; Liu, L.; Suchard, M.A.; Huelsenbeck, J.P. Mrbayes 3.2: Efficient bayesian phylogenetic inference and model choice across a large model space. Syst. Biol. 2012, 61, 539-542. [CrossRef]

38. Darriba, D.; Taboada, G.L.; Doallo, R.; Posada, D. jModelTest 2: More models, new heuristics and parallel computing. Nat. Methods 2012, 9, 772. [CrossRef]

39. Wee, N.Q.X.; Cutmore, S.C.; Cribb, T.H. Four new monorchiids from the golden trevally, Gnathanodon speciosus (Forsskål) (Perciformes: Carangidae), in Moreton Bay, Australia. Syst. Parasitol. 2019, 96, 265-278. [CrossRef]

40. Rambaut, A.; Drummond, A.J. FigTree Version 1.4. 2012.

41. Bray, R.A.; Cribb, T.H.; Cutmore, S.C. Lepocreadiidae Odhner, 1905 and Aephnidiogenidae Yamaguti, 1934 (Digenea: Lepocreadioidea) of fishes from Moreton Bay, Queensland, Australia, with the erection of a new family and genus. Syst. Parasitol. 2018, 95, 479-498. [CrossRef]

42. Bray, R.A.; Cutmore, S.C.; Cribb, T.H. Lepotrema Ozaki, 1932 (Lepocreadiidae: Digenea) from Indo-Pacific fishes, with the description of eight new species, characterised by morphometric and molecular features. Syst. Parasitol. 2018, 95, 693-741. [CrossRef] 
43. Manter, H.W. The digenetic trematodes of marine fishes of Tortugas, Florida. Am. Midl. Nat. 1947, 38, 257. [CrossRef]

44. Sparks, A.K. Some digenetic trematodes of marine fishes of the Bahama Islands. Bull. Mar. Sci. 1957, 7, 255-265.

45. Sogandares-Bernal, F. Digenetic trematodes of marine fishes from the Gulf of Panama and Bimini, British West Indies. Tulane Stud. Zool. 1959, 7, 71-117.

46. Nahhas, F.M.; Cable, R.M. Digenetic and aspidogastrid trematodes from marine fishes of Curaçao and Jamaica. Tulane Stud. Zool. 1964, 11, 169-228. [CrossRef]

47. Rees, G. Some helminth parasites of fishes of Bermuda and an account of the attachment organ of Alcicornis carangis Maccallum, 1917 (Digenea: Bucephalidae). Parasitology 1970, 60, 195-221. [CrossRef] [PubMed]

48. Nagaty, H.F.; Abdel-Aal, T.M. Trematodes of fishes from the Red Sea, Part 20. On four monorchiids, including a new genus and three new species. J. Egypt. Veternary Med. Assoc. 1972, 32, 207-213.

49. Fischthal, J.H. Some sigenetic trematodes of marine fishes from the barrier reef and reef lagoon of Belize. Zool. Scr. 1977, 6, 81-88. [CrossRef]

50. Kohn, A.; Macedo, B.; Fernandes, B.M.M. About some trematodes parasites of Haemulon sciurus (Shaw, 1803). Mem. Inst. Oswaldo Cruz 1982, 77, 153-157. [CrossRef]

51. Centeno, L.; Bashirullah, A. Comunidades de parásitos metazoos en ocho especies de peces del género Haemulon (FAM: Haemulidae) del Golfo de Cariaco, Venezuela. Ciencia 2003, 11, 119-124.

52. Bashirullah, A.K.; Díaz, M.T. Helminth infracommunity of Haemulon aurolineatum Cuvier, 1830 (Haemulidae) from the Gulf of Cariaco, Venezuela. Rev. Cient. la Fac. Ciencias Vet. la Univ. del Zulia 2015, 25, 167-172.

53. Dyer, W.; Williams, E.; Bunkley-Williams, L. Homalometron dowgialloi sp. n. (Homalometridae) from Haemulon flavolineatum and additional records of digenetic trematodes of marine fishes in the West Indies. J. Helminthol. Soc. Wash. 1992, 59, 182-189.

54. Curran, S.S.; Overstreet, R.M.; Tat The, D.; Thi Le, N. Singhiatrema vietnamensis sp. n. (Digenea, Ommatobrephidae) and Szidatia taiwanensis (Fischthal and Kuntz, 1975) comb. n. (Digenea: Cyathocotylidae) from colubrid snakes in Vietnam. Comp. Parasitol. 2001, 68, 219-227.

55. Curran, S.S.; Tkach, V.V.; Overstreet, R.M. A new species of Homalometron (Digenea: Apocreadiidae) from fishes in the Northern Gulf of Mexico. J. Parasitol. 2013, 99, 93-101. [CrossRef]

56. Linton, E. Helminth Fauna of the Dry Tortugas. Pap. Tortugas Lab. Carnegie Inst. Wash. 1910, 1, 157.

57. Parasitology Laboratory. Investigation of parasites in sea eel from Fujian. J. Fujian Norm. Univ. Nat. Sci. Ed. 1976, 1, 108-112.

58. Carella, F.; Culurgioni, J.; Aceto, S.; Fichi, G.; Pretto, T.; Luise, D.; Gustinelli, A.; De Vico, G. Postmonorchis sp. inq. (Digenea: Monorchiidae) metacercariae infecting natural beds of wedge clam Donax trunculus in Italy. Dis. Aquat. Org. 2013, 106, 163-172. [CrossRef]

59. Mancini, E.; Furfaro, G.; Cervelli, M.; Di Giulio, A.; Oliverio, M.; Salvi, D.; Mariottini, P. Molecular detection of parasites (Trematoda, Digenea: Bucephalidae and Monorchiidae) in the European flat oyster Ostrea edulis (Mollusca: Bivalvia). Eur. Zool. J. 2018, 85, 8-16. [CrossRef]

60. Ferrer-Maza, D.; Muñoz, M.; Lloret, J.; Faliex, E.; Vila, S.; Sasal, P. Health and reproduction of red mullet, Mullus barbatus, in the western Mediterranean Sea. Hydrobiologia 2015, 753, 189-204. [CrossRef]

61. Knoff, M.; Amato, J.F. Nova especie do genero Genolopa Linton, 1910 (Monorchiidae, Lasiotocinae) parasite de tainha, Mugil platanus Gunther, 1880 da costa de estado do Rio de Janeiro, Brasil *. Rev. Bras. Biol. 1991, 51, 801-804.

62. Siddiqi, A.H.; Cable, R.M. Digenetic trematodes of marine fishes of Puerto Rico. Scientific Survey of Porto Rico and the Virgin Islands 1960, 17, 256-369.

63. Overstreet, R.M. Digenetic trematodes of marine teleost fishes from Biscayne Bay, Florida. Tulane Stud. Zool. Bot. 1969, 15, 119-176.

64. Lozano, C.; Úbeda Ontiveros, J.; Rojas Álvarez, M.; Ariza Astolfi, C.; Guevara Benítez, D. Estudio de digénidos de peces marinos del sur de la Península Ibérica. Rev. Iber. Parasitol. 2001, 61, 103-116. 
65. Mosquera, O.; Mago, Y.; Chinchilla, O. Finding of Genolopa ampullacea Linton, 1910 (Digenea: Monorchiidae, Monorchiinae) in Haemulon bonariense Cuvier, 1830 from Mochima Bay, Sucre State, Venezuela. Saber 2014, $26,121-126$.

66. Overstreet, R.M.; Brown, C.E. Lasiotocus trachinoti sp. n. (Digenea: Monorchiidae) from the pompano, Trachinotus carolinus (Linnaeus), along the East Coast of Florida. J. Parasitol. 1970, 56, 941-943. [CrossRef]

(C) 2020 by the authors. Licensee MDPI, Basel, Switzerland. This article is an open access article distributed under the terms and conditions of the Creative Commons Attribution (CC BY) license (http://creativecommons.org/licenses/by/4.0/). 